\title{
BÁNDI ANDRÁS - SZABÓ ANDRÁS PÉTER \\ Hajdú István törcsvári porkoláb kéziratos kötete - Két ismeretlen magyar vers Báthori Gábor fejedelem korából
}

\begin{abstract}
A Romániai Evangélikus Egyház nagyszebeni székhelyü központi levéltárában (Zentralarchiv der evangelischen Kirche A. B. in Rumänien) öriznek egy börkötéses kéziratot, fedelén a „Ung(arisches) Gesetz-Buch u(nd) anderes” („Magyar törvénykönyv és egyebek") felirattal. ${ }^{1}$ A Hajdú István (1687-1748) törcsvári porkoláb által elkezdett kötet korábban a Sinki Káptalan (a későbbi Sinki, Ágotai és Szebeni Egyházmegye) ${ }^{2}$ tulajdonát képezte és 2001-ben szállították be a gyüjtőlevéltárba. Több mint valószínü, hogy (III.) Szeli József (1741-1815), Nagysinkszék királybírája ${ }^{3}$ adományozta a nagysinki evangélikus iskolának. Innen került a káptalan iratanyagát őrző helyi egyházközséghez. A királybíró a kéziratot apjától, (II.) Szeli József (1710-1782) brassói és hosszúfalui evangélikus lelkésztől, Hajdú István vejétől örökölte. ${ }^{4}$ A kézirat útja tehát a Barcaságtól Nagysinkig, a porkolábtól a királybíróig világosan kirajzolódik. Jelen közleményben a történeti és irodalomtörténeti kutatás számára eddig ismeretlen kötet rövid bemutatására és néhány benne szereplő forrás kiadására vállalkozunk.
\end{abstract}

${ }^{1}$ A címkén az 1723-as évszám, valamint a 14-es jelzetszám olvasható.

2 Az Ágotai Egyházmegyét 1951-ben hozták létre a Kultuszminisztérium azon javaslatára, hogy az egyházmegyék határai egybeessenek a rajonokéval (járásokéval). Az újonnan keletkezett egyházmegyéhez 40 gyülekezet tartozott, ebből 24 a volt Sinki Egyházmegye része. A következő átszervezésre 1968-ban került sor, amikor a Román Szocialista Köztársaság bevezette a megyerendszert (judeţ). Az Ágotai Egyházmegyét feloszlatták, egyik része a Medgyesi, a másik a Szebeni Egyházmegyéhez került. Evangélikus Egyház Központi Levéltára, Nagyszeben, Főkonzisztórium (Bestand Landeskonsistorium) 103-422/1951; 103-467/1968.

${ }^{3}$ (III.) Szeli József írásos hagyatékának nagyobb része a Szentágotai Városi Múzeumba (Jelenleg: Muzeul de istorie Valea Hârtibaciului) került, ám a múzeumi könyvtár kéziratos anyagait az 1970-es években átadták a Szebeni Állami Levéltárnak, ahol önálló fondot alakítottak ki belőle, a „Szentágotai múzem iratgyüjteménye” (Colecţia de documente ale muzeului Agnita) elnevezéssel. - (III.) Szeli Józsefről: GuNESCH, Hans, Ein evangelischer Ungar als Königsrichter des Groß-Schenker Stuhles = Zeitschrift für Siebenbürgische Landeskunde, 75(1981), 2, 150-156; BINDER Pál, Az erdélyi magyar evangélikus egyházközségek és iskolák története és névtára (15421860), Brassó, Brassói Evangélikus Egyházmegye, 1993, 102-104.

${ }^{4}$ (II.) Szeli József életéről: Binder 1993, i. m. 98-102; könyves ügyeiről lásd 1734. augusztus 22-én Fábri Gergelyhez írott levelét (PAYR Sándor, Magyar Protestáns Egyháztörténeti Adattár, II. köt., Budapest, 1903, 169-170., újraközlése: Erdélyi könyvesházak III, sajtó alá rendezte Monok István, Németh Noémi, Varga András, Szeged, Scriptum, 1994, 302-303). 
A kéziratot vezetni kezdő Hajdú István a barcasági magyar evangélikus értelmiség jellegzetes képviselője (lásd a mellékelt családfát). Nagyapja, Hajdú Miklós, II. Rákóczi György egykori vitéze, annak 1657. évi lengyelországi hadjárata után a Hétfalu részét képező Türkösön, tehát Brassó szász város egyik magyar jobbágyfalvában telepedett meg, és itt mintegy negyven éven át viselte a folnagyi (bírói) tisztet. (Még az 1698. évi összeírás idején is ebben a minőségben szerepelt.) ${ }^{5}$ Apja, idősebb Hajdú István (1660-1694) rövid brassói iskolamesterség után 1686. május 18-től a brassói magyar evangélikusok lelkésze volt, majd 1690-ben a várost átmenetileg hatalmába kerítő Thököly Imre, mint lutheránus és magyarul prédikálni tudó egyházit, udvari lelkészévé nevezte ki. Három éven át a törökországi számüzetésben is a fejedelemmel maradt, majd 1693-ban Thököly engedélye nélkül hazatért. Brassóban féléves fogságot szenvedett, kiszabadult, ám ezt követően rövid időn belül meghalt. ${ }^{6} \mathrm{Az} 1687$ augusztusában született ifjabb Hajdú Istvánt így hét éves korától özvegy édesanyja, Gothárd Jakab brassói magyar evangélikus lelkész (1675-1686) ${ }^{7}$ leánya, nemes Gothárd Mária nevelte. A fiút eredetileg alighanem szintén egyházi pályára szánták. Valamikor a 17-18. század fordulóján ismeretlen ideig a Székelyudvarhelyi Református Kollégiumban diákoskodott. ${ }^{8}$ (Bevett szokás volt a 17. század végéig a barcasági magyar evangélikus értelmiség körében, hogy gyermekeiket, a névleges dogmatikai különbségek ellenére, református intézményekbe küldték tanulni.) 1703-ban azonban meghalt az édesanyja, és a fiú tanulmányai félbeszakadtak. A Rákóczi-szabadságharc alatt beállt a császári hadsereg Brassóban megszervezett „szabad századába,” tehát a fejedelem kurucai ellen harcolt. ${ }^{9}$ A háború végeztével Brassó város szolgálatába állt, az alább

5 BINDER 1993, i. m. 11.

${ }^{6}$ Binder 1993, i. m. 59-60. Binder Pál, Brassói magyar krónikások és barcasági evangélikus egyháztörténészek (1550-1800), Szecseleváros, 2000, 82.

7 Binder 1993, i. m. 55-57. A gyászbeszéd arról nem tudósít, hogy Mária a Gothárd család melyik tagjának volt a leánya, de segítségünkre siet dálnoki Gothárd Jakab brassói magyar lelkész 1676. nov. 18-án kelt, Apafi Mihály fejedelemtől kapott újító címeres nemeslevele, amelyben felsorolják az adományos gyermekeit: Jánost, Lőrincet, Máriát, Krisztinát és Annát. ÁldÁsy Antal, A Magyar Nemzeti Múzeum könyvtárának czímjegyzéke II. Címereslevelek, 4. köt. (1657-1716), Bp., Magyar Nemzeti Múzeum, 1938, 158-159. (No. 11.) Áldásy az irat tartalmi kivonatát egy 20. századi másolat alapján közölte, eredetijét Brassó város levéltárában őrizték. A címeres nemeslevél külön érdekessége, hogy Gothárd Jakab brassói református lelkészként szerepel benne.

8 Az intézmény 1670 és 1769 között vezetett első anyakönyvének kiadásában (Székelyudvarhely református és katolikus diáksága 1670-1871, kiad. Albert Dávid, Szeged, Szegedi Tudományegyetem, 2004, 23-76.) Hajdú István nevét hiába keressük, ez azonban valószínúleg csak a forrás hiányaira vezethető vissza.

9 A szabad századok (frei Compagnien) alacsony harcértékü, ezredkötelékbe nem tartozó helyőrségi alakulatok voltak, a reguláris alakulatoktól némileg eltérő szervezeti formában, más rendszerü ellátással és kisebb zsolddal. 100, 200 illetve 300 fös keretlétszámú századok léteztek. Köszönjük Mészáros Kálmán és Czigány István e tárgyban nyújtott tájékoztatását. A 17. századi szabad századokról: Czigány István, Reform vagy kudarc, Kísérletek a magyarországi katonaság beillesztésére a Habsburg Birodalom hadseregébe 1600-1700, Bp., Balassi Kiadó, 2004, 132-135, 143-147. 
közölt gyászbeszéd tanúsága szerint 1726-tól a „városi szolgák öreglegénye”, azaz a város rangidős familiárisa volt. Végül 1735-től 1748-ban bekövetkezett haláláig törcsvári porkolábként müködött. ${ }^{10} \mathrm{~A}$ barcasági magyar evangélikusok körében ez a poszt számított az elérhető legmagasabb tisztségnek. A törcsvári porkoláb - 1625-től az erdélyi fejedelmek akaratának megfelelően mindig magyar anyanyelvü személy - az uradalomnak a törcsvári várban székelő, közigazgatási és igazságszolgáltatási funkciókkal is bíró irányítója volt. ${ }^{11} \mathrm{Az}$ uradalomhoz tartozott a Hétfalun kívül két másik magyar ajkú település, Apáca és Krizba is. Bár tisztsége elvileg Törcsvárhoz kötötte, úgy tünik, hogy Hajdú nem tartózkodott állandó jelleggel ott, hiszen ahogy 1735 elött, úgy 1741-ben is Brassó magyar külvárosának, Bolonyának lakójaként említette magát. ${ }^{12}$ Valószínúleg napi vagy heti rendszerességgel kijárt a várostól 28 kilométerre fekvő erősségbe. Végső soron csaknem egész élete a Barcasághoz és Brassóhoz kötődött.

A kéziratot számos szöveggel bővítette második tulajdonosa, Hajdú István veje, (II.) Szeli József is. Szeli annak a (I.) Szeli Györgynek unokája volt, aki valamikor a 17. század közepén jött a Csallóközből a fejedelemségbe, hogy a 18. századi Erdély egyik meghatározó magyar evangélikus lelkészdinasztiájának ősatyja legyen. ${ }^{13}$ A Szeliek Hajdúval ellentétben már egy új korszak képvise-

${ }^{10}$ A brassói hivatalnoki karról a 20. század elején készített archontológia 1733 és 1739 közé teszi Hajdú István törcsvári porkolábi múködését. (STENNER, Friedrich, Die Beamten der Stadt Brassó (Kronstadt) von Anfang der städtischen Verwaltung bis auf die Gegenwart, Quellen zur Geschichte der Stadt Brassó (Kronstadt) Bd. VII.1, Brassó (Kronstadt), Buchdruckerei Brüder Schneider \& Feminger, 1916, 59.) A nagysinki kötetben szereplö életrajz információi ezt jelentősen pontosítják.

${ }^{11}$ Georg Eduard Müllernek az erdélyi szász közigazgatás történetéről 1941-ben írott alapműve a törcsvári uradalomról és porkolábjairól elég homályosan, valószínúleg két különböző tisztséget összemosva beszél. (Georg Eduard MüLLER, Stühle und Distrikte als Unterteilungen der Siebenbürgisch-Deutschen Nationsuniversität 1141-1876, Köln, Wien, Böhlau Verlag, 1985 [Schriften zur Landeskunde Siebenbürgens, 10], 276-277.) A brassói belső tanácsnak két tagja felelt a törcsvári uradalom ügyeiért. A terület fontosságát mutatja, hogy egyikük rendszerint maga a város aktuális bírája volt, míg a másik a sorrendben elöző bíró. (Von Herrmann, George Michael Gottlieb, Das alte und neue Kronstadt, Eine siebenbürgische Stadt- und Landesgeschichte bis 1800, Hrsg. Bernhard Heigl, Thomas Şindilariu, Köln, Weimar, Wien, Böhlau Verlag, 2010 [Schriften zur Landeskunde Siebenbürgens, 32], 310-314.) A két szász szenátort ebben a referensi-felügyelői funkciójukban latinul castellanusnak (Törzburger Kastellan) hívták. Létezett azonban az uradalomnak egy másik tisztviselöje is, aki a város alkalmazottjaként a mindennapi, gyakorlati munkát végezte, ő volt a németül is általában „Porkolab”-ként említett porkoláb. (1612-ben még két ilyen porkolábot említenek, akik közül az egyik, az „Oberst-Porkolab” magasabb rangú.) Az elterjedt félreértés arra vezethető vissza, hogy a porkoláb latin szövegekben szintén castellanusként szerepel. A kérdés teljes, a 17-18. század folyamán bekövetkezett változásokat is feltáró vizsgálata természetesen nem lehet közleményünk feladata. A brassói levéltárban őrzött törcsvári számadások (Törzburger Castellansrechnungen) segítségével (amelyeket a két szenátor vezetett) alighanem a még homályos részleteket is meg lehetne világítani.

12 DÉzsI Lajos, Régi magyar verseskönyvek ismertetése, I, A Csereyné-codex = Irodalomtörténeti Közlemények, 21(1911), 59.

13 Binder 1993, i. m. 95-96. 
lői, amikor a berethalmi székhelyü szász püspökség a helyi, hétfalusi csángó gyökerekkel bíró, iskolázásuk folytán sokszor református hitelveket valló papokat igyekezett máshonnan odaszármazott, de valóban lutheránus lelkészekkel felváltani. ${ }^{14} \mathrm{~A}$ barcasági úgynevezett kriptokálvinizmus ellen határozottan fellépő (II.) Szeli József brassói (1735-1757), hosszúfalui (1757-1763) és szászzsombori (1763-1782) magyar evangélikus lelkész a fenti jelenségnek ékes példáját adja. ${ }^{15}$ Hajdú István leányával, Hajdú Krisztinával 1735-ben kötött házassága viszont tulajdonképpen két korszak találkozását, két rokonsági háló összekapcsolódását jelentette. 1675-ben Gothárd Jakab éppen a vonalas lutheránus (I.) Szeli Györgyöt váltotta - állítólag a református fejedelem, Apafi Mihály akaratából - a brassói magyar lelkészi poszton. ${ }^{16}$ Dédunokája azonban már Szeli György unokájának, a másik irányzat zászlóvivőjének lett a felesége.

Miután röviden felvázoltuk az összetett forrás keletkezésének társadalmi hátterét, fordítsuk figyelmünket magára a kéziratra. A belső kötéstáblán a nagysinki evangélikus iskola pecsétjét és jelzetét találjuk, ${ }^{17}$ valamint a következő szöveget: „Ezékhiel XVI. v(ers). 44 Jeremiás 22. v(ers). 10. Zach(ariás). XI. v(ers). 17. Jeremiás XVII. v(ers). XI." ${ }^{18}$ Ezt a bejegyzést Hajdú készíthette, mivel stílusa (nyomtatott kezdőbetük használata) megegyezik a többi általa bemásolt szövegével. Az előzéklapon olvashatjuk a könyv tartalomjegyzékét, egy kései, talán 19. századi kéztől, latinul. A hátoldalon két román nyelvủ esküszöveg olvasható: „Formula Juramenti Wallachici Ordinarioru(m)” és „Alia Strictior(um)”.

A kötetbe előbb Hajdú István másolt be jogi, erkölcstani és orvosi témájú írásokat. Ezekhez társulnak anyakönyvi jellegü feljegyzések, két egyetemes történeti vonatkozású szöveg, valamint két vers. A törcsvári porkoláb minden bizonnyal azért kezdett neki ennek a kéziratos kötetnek, hogy hivatali tevékenységében segítségére legyen. Ezzel magyarázható a tény, hogy a legelső, jogi jellegü írást pedánsan, szinte kalligrafikus minőségben jegyzi le. A többi szöveg viszont már nem ilyen esztétikai színvonalon készült el, jelezve, hogy ezek már személyes használatra szánt szövegek. Hajdú István három írást jelöl meg, mint saját keze által bemásoltat. A többiekről (szám szerint hatról) feltételezzük csupán, hivatkozva a kézírás hasonlóságára. Mindazonáltal megjegyezendő, hogy Hajdú

14 Binder 1993, i. m. 15-23.

15 Binder 1993, i. m. 98-102.

16 Binder 2000, i. m. 82.

17 „Gr. Schenker Schulbibliothek 3066”.

18 „Aki szereti a szólásokat, ezt a szólást fogja majd mondani rád: Amilyen az anya, olyan a leánya.” (Ezékiel 16,44) „Ne a halottat sirassátok, és ne azt sajnáljátok! Azt sirassátok, aki elmegy, mert nem tér vissza többé, nem láthatja viszont szülőföldjét.” (Jeremiás 22,10) „Jaj a mihaszna pásztornak, aki elhagyja a nyájat! Fegyver járja át a karját meg a jobb szemét! Száradjon le a karja, vakuljon meg a jobb szeme!” (Zakariás 11,17) „Aki törvénytelenül gyüjt gazdagságot, olyan, mint a madár, amely idegen tojásokon ül. Élete derekán itt kell hagynia, és a végén bolondnak tartják." (Jeremiás 17,11) - Felhasznált fordítás: revideált Károli biblia, lásd: www.abibliamindenkie.hu. (2016. nov. 15.) 
nem konzekvens, bizonyos betűk alakja eltér egymástól akár ugyanazon az egy oldalon is.

(II.) Szeli József csak egy mű címlapjára tünteti fel nevét, illetve az anyakönyvi jellegü családi krónikának folytatásaként megemlíti apósának, anyósának, sógorainak stb. elhalálozását. Az utóbbi alapján sikerült megállapítani kézírását. Az ő esetben is észrevehetőek kis eltérések a szövegek kalligráfiája között, de nem szabad megfeledkezni arról, hogy mindkettőjüknél nagy, pár éves, akár évtizedes távlatokról beszélhetünk a különböző szövegek lejegyzése között. Szeli egy játéknak szánt „tréfás” jóskönyvet, egy terebélyes egyházjogi szöveget, valamint Erdély alaptörvényének kivonatát másolja be. Az utóbbi kettőnél, egy-egy későbbi kéz írja meg az utolsó oldalakat. Abból kell kiindulni, hogy arról, ami nincsen aláírva, csupán feltételezzük, hogy a lelkész kezének munkája. Nála is a szakmai érdek lehetett elsődleges.

Az első bemásolt szöveg a szász nemzet törvénykönyvének (Eigenlandrecht) magyar fordítása (1-62), ${ }^{19}$ amelyet Hajdú István jegyzett le. A szöveget így fejezi be: „Finis Decreti Septem et duarum Sedium Saxonicalium in Transylvania Constitutarum Scripsit Stephanus Hajdu In Anno 1723 Die 6ta Maÿ"20. A könyvet 1583-ban adta ki először Matthias Fronius Brassóban, előbb német, majd latin nyelven. ${ }^{21} \mathrm{~A}$ kora újkorból magyar nyelvü nyomtatott kiadása nem ismert. Hajdú, akiről nem tudjuk, hogy maga fordította a nyomtatványt, vagy csak lemásolta annak egy kéziratos fordítását, kihagyta a mủ előszavát. A Dekrétum négy könyvét egy betürendes index követi. A nagyszebeni Brukenthal-gyüjteményben található egy ennél későbbre keltezett és nyelvileg gondosabban megfogalmazott szöveg: „Az Erdély-Országi Szász-Nemzetnek Szabad Polgári-Törvénye, Elsőben Néhai Tekintetetes Frónius Máttyás Brassai Tanátsbéli Ur munkája által, Deák és Német nyelveken, a’ a Királyi Diplómás Könyvek rendi szerint ki-botsáttatott; Annak-utánna penig Magyar nyelvre fordítatván, Szebenben Kéz-írásban ki-adattatott az M. DCC. LVI. Esztend(őben). ${ }^{.22}$ Ennek a másik, 1756-ra keltezett kötetnek, amely ezen kívül még tartalmaz a szászokra vonatkozó kivonatokat Werbőczi Tripartitumából, valamint a Approbatae Constitutiones-böl is, nem ismerjük tulajdonosát, ${ }^{23}$ de a szövegek fordítóját sem. Nehéz megállapítani, hogy áll-e a jogkönyv két változata egymással összefüggésben vagy sem. Mégis lehetséges, hogy egy közös forrást használhattak, mivelhogy az eltérések többnyire

19 „Erdély országába lako szászoknak szabad varosoknak tartományoknak irott decretoma”. Ungarisches Gesetz-Buch, 1. A szövegben későbbi, idegen kéz által készített jegyzetek találhatóak.

${ }^{20}$ Ung. Gesetz-Buch, i. m. 54.

${ }^{21}$ Hosszabb szünet után 1721-ben jelent meg újra az Eigenlandrecht, Johann Barth nagyszebeni nyomdájában. Elképzelhető, hogy a fordítás ehhez az újrakiadáshoz is kapcsolódik. Petrik Géza, Magyarország bibliographiája, III, Bp., Dobrowsky Ágost, 1890, 430.

${ }^{22}$ Arhivele Naţionale Direcţia Judeţeană Sibiu, Colecţia Brukenthal, (A továbbiakban: ANDJS Col. Brukenthal) A, 1-5. Nr. 60, A kézirat tartalmaz a szöveg törzsén kívül címlapot, ajánló bibliai verseket, valamint előszót is.

${ }^{23}$ A bőrkötéses fedőn olvasható a következő felirat olvasható: „S. V. 1757”. 
stilisztikaiak. A kéziratok mondatszerkezete és szókincse ugyanaz. Példaképpen idézzük az 1. könyv 2. titulusát:

\section{3}

Szükség és hasznos dolognak tettzék penig hogy az valasztásban bizonyos rend tartassék, mert a ki Fö Tisztben volt arra terhet nem kell vetni, az ki penig valami terhes Gondviselésben volt arra tisztet athatnak mert Fö Tiszteket viseltenek, hogy azokot aláb valo Tisztre ne Szálitsák az okoságis meg mutattya, eszt hozzá tévén hogy az Ditsiretes jo szokás régtöl fogván az hellyhez és idöhöz képest mindenütt éppen meg maradgyon. ${ }^{24}$

\section{6}

Tehát szükség és hasznos dolognak tetszett lenni, hogy a' választásban bizonyos rend tartassék meg: Mert, a' ki fó tisztben volt, arra terhet nem kell vetni: A' ki penig valami terhes gond-viselésben volt, arra tisztet adhatnak: Mert fö tiszteket viseltenek, hogy azokat alább-való tisztre ne szállítsák az okosság meg-mútatja, ezt hozzá-tévén hogy, a' ditséretes régi jó szokás az helyekhez és időkhöz képest mindenütt és mindenkor épen meg-maradjon. ${ }^{25}$

A jogtörténeti szakirodalom egyébként tud róla, hogy a nem szászföldi, de szász joggal élő Vízaknán (Fehér megye) egészen 1853-ig használták az Eigenlandrecht egy 18 . századi magyar fordítását. ${ }^{26}$ Könnyen lehet, hogy ez a lappangó szöveg is kapcsolatba hozható a jelenleg ismert két kézirattal.

A kötet 63. oldalán jegyezte fel Hajdú azon ajándékokat, amelyekkel a felszentelendő pap a püspöknek tartozott, valamint itt kapott helyet a „Szentelésnek idején valo költésnek fel jedczése" is.

A következő bejegyzés egy szinte negyvenoldalas, magyarra fordított kivonat (65-102) a Jules Mazarin (1602-1661) francia államférfi és bíborosnak tulajdonított Breviarium politicorum címü, latin nyelvü politikaelméleti munkából. A mủ első kiadása 1684-ben látott napvilágot Kölnben, amit a 17. és 18. században számos további kiadás követett. Ennek a résznek az írnoka is Hajdú István, aki utólag bejegyzi minden fejezet eredeti oldalszámát a következő szöveggel: „Láthatod a' nyomtatott Deák Exemplaromnak Lapjait.”27 Az oldalszámok megegyeznek példának okáért az 1708-as és 1721 -es kiadásokéval.

Ezt követi egy magyar nyelvű, orvosi témájú verses mủ másolata: „De Conservanda Bona Valetudine Liber Scholae Salernitanae. Az Anglia Orszagban lévő

${ }^{24}$ Ung. Gesetz-Buch, i. m. 1.

25 ANDJS Col. Brukenthal, A, 1-5. Nr. 60, 3.

26 Schuler von Libloy, Friedrich, Siebenbürgische Rechtsgeschichte II, Die siebenbürgischen Privatrechte, Hermannstadt, Buchdruckerei der v. Closius'schen Erbin, 1868, 206. (2. lábjegyzet) - Itt köszönjük meg Derzsi Júliának, hogy erre az adatra, és a Brukenthal gyüjteményben őrzött kéziratra felhívta a figyelmünket.

${ }^{27}$ Ung. Gesetz-Buch, i. m. 66. 
Salernitana Scholanak Jo Egessegről Valo Meg-Tartásnak modgyárol, irott Könyve Melly Most Magyarra fordittatott és Rhytmusokban alkalmaztattot Felvinczi György Lőtsén Nyom(tatta). Brever Samuel 1694.” (103-140)28 A bemásolása szintén Hajdú érdeme: „De irta Bolonnyában lako Hajdu istván az 1732 Esztendőben, Böjt elő Havának Hetedik és következendő napjaiban.” A „címlap” hátoldalán immár Szeli József jegyzi fel, hogy ő is rendelkezik egy 1617-ben, Frankfurtban megjelent deák példánnyal. A 127. oldalon befejeződik a Schola Salernitana, de Hajdú hozzácsatol egy „Tholdalék”-ot, amely gyógyító és háztartási recepteket tartalmaz. Ezeket kiegészítette a 138. és 139. oldalon egy idegen kéz.

Majd egy német nyelvű munka fordítását másolja be Szeli József (141-172), a következő címmel: „Nevetséges és múlatság(os). Az az Négy sorban irt „punctumok"-nak meg számlálásából kihozott tréfás practika, és kinek kinek elméjének Megfejtése, Melly Elsőbben iratott Arabiai nyelven, és abból Német nyelvre forditatván, ki-nyomtattatott Gros János maradékinál Lipsiaban 1728. Esztendőben. Most pedig Tréfás mulatság végett Magyar nyelvre forditatott 1751. Esztendőben.” A német változat címe: „Curieuse und Gantz neue Art Zum Punctiren / Noch niemahls im Druck gesehen, Jetzo aus dem Arabischen ins Teutsche übersetzet Von Einem Liebhaber dieser Kunst." 29 A geomantiai tárgyú jóskönyvet talán maga Szeli fordította magyarra, mert ilyen címủ magyar nyomtatványt a magyar könyvtörténeti szakirodalom nem ismer.

Az 173-254. oldalakon találjuk Martin Harnung brassói plébános (vezető lelkész) 1659-ben összeállított munkájának, az Encheiridionnak (teljes címe: ENXEIPI $\triangle I O N$ B. Martini Harnungi) egy másolatát. ${ }^{30}$ Ennek írnoka már (II.) Szeli József. A kézikönyv nem más, mint egy egyházjogi szöveggyűjtemény a barcasági egyházközségek számára. A Brassóban őrzött eredeti tartalomjegyzéke 26 olyan fejezetet sorol fel, amelyet a Szeli-féle másolat nem tartalmaz. Köztük található a káptalan statútuma 1590-ből, kivonatok egy korábbi kéziratból (Ex veteri Capituli Codice), amely 15 és 16. századi információkkal szolgál

${ }^{28}$ RMK I. 1459. Felvinczi György versfordításának modern kiadása: Régi magyar költők tára, XVII. század, 13, kiad. Varga Imre, Bp., Akadémiai Kiadó, 1988, 130-158. A vonatkozó jegyzetek: 591-608.

${ }^{29}$ A német nyelvü, Szeli által pontosan leírt címü munka jelenlegi ismereteink szerint 1702-ben jelent meg elöször Lipcsében, impresszum nélkül: VD18 10968644. Az 1714. évi, Lipcsében, Johann Gross örököseinél megjelent kiadás bizonyos R. S-t tüntet fel fordítóként. (VD 18 11090421) A Szeli által említett 1728. évi kiadás egy példánya a Bayerische Staatsbibliothekban maradt fenn. Ez digitalizálva is elérhető: http://reader.digitale-sammlungen.de/resolve/display/bsb10133225.html

30 Martin Harnung (1625-1703), Brassóban született, 1641-ben a gimnázium diákja, majd 1651-től kezdődően annak tanárja. 1655 és 1658 között brassói prédikátor, majd 1691-ig Botfalun lelkipásztor, amikor a brassóiak megválasztják plébánosukká. 1678-al kezdődően a Barcasági Káptalan többszöri dékánja. WAGNer, Ernst, Die Pfarrer und Lehrer der Evangelischen Kirche A. B. in Siebenbürgen, I. Band, Von der Reformation bis zum Jahre 1700, Köln, Weimar, Wien, Böhlau Verlag,1998 [Schriften zur Landeskunde Siebenbürgens Band, 22/I], 208. Az eredeti kézirat a brassói Fekete templom levéltárában (Archiv der Honterusgemeinde - a továbiakban: AH) őrzik, jelzete: I.F.66. Ugyanott őrzik Matthias Aerkeder szintén 1758-ban elkészített másolatát: IV.F.1.Tq. 98. 
- föképp a káptalan és papjai érdekében tett adományokról, eskütételek szövegei, a nyolc szász káptalan sematizmusa (Catalogus VIII Capitulorum Parochialium in Transilvania, quorum priora Tria spectant ad Dioecesin Strigoniensem, posteriora Quinque ad Dioecesin Albensem ex Regesto M(agistri) Joannis Honteri Coronensis descriptus). ${ }^{31} \mathrm{~A}$ továbbiakban olyan szövegekkel találkozunk, amelyek a tizedet, a papoknak járó adókat, a káptalan kiváltságait, különböző ünnepek megülését stb. ismertetik. Végül a káptalan lelkészi archontológiája következik (series pastorum). A lelkészlisták eltérnek egymástól. Szeli három oszlopba helyezi a lelkész szolgálati idejét a következőképpen: a szolgálat kezdetének dátuma, időtartama években, a távozás, illetve elhalálozás dátuma. Megjegyezendő, hogy az eredeti, Fekete templomi kéziratban, bizonyos községek listáit folyamatosan bővítették az elkövetkezendő évszázadokban, így például a feketehalmi eljut 1835-ig. A másolat végén egy megjegyzést találunk arról, hogy Harnung sem tudta összegyüjteni a kilenc magyar evangélikus község lelkészeinek adatait, erre maga Szeli vállalkozott, de írásos feljegyzések híján az idősebbek puszta emlékezetére kellett támaszkodnia. ${ }^{32} \mathrm{~A}$ barcasági magyar evangélikus lelkészek felsorolása végül a határozott ígéret ellenére kimaradt a kötetből, Szeli állítása szerint azért, mert lelkészlistáit Petrus Clos brassói plébános (1757-1771) kölcsönkérte tőle, de sosem adta vissza, hanem az egyes egyházközségek anyakönyveinek elejére illesztette. Szeli József amúgy következetesen hoz a magyarokra vonatkozó kiegészítéseket a szöveg legvégén vagy margón.

Az Encheiridion tartalmazza a barcasági egyházközségek javainak összeírását is német változatban, amelyet Szeli is átvett. ${ }^{33}$ Ezt követi a barcaszentpéteri egyházközség statútuma, valamint a Barcasági Káptalan vizitációs szabályai (1578). Szeli kihagy viszont két írást: „Ordnung u(nd). Recht Den Zehendern

${ }^{31}$ A Szeli-kéziratba bejegyezték, hogy Martin Schmeizel a De Statu Ecclesiae Lutheranorum in Transilvania címü értekezésében (Jéna, 1722) a káptalanok másképp vannak feltüntetve. Ung. Gesetz-Buch, i. m. 183.

32 „Notandum. Pastores Ungaro-evangelicos a temporibus inde reformationis Barcia et in libera regiaque civitate Coronensi, et in novem praediis Ungaricis habitos fuisse Enchiridion Harnungianum ad annum 1544 testatur, vide paginam mihi 40. Seriem tamen et catalogum pastorum nec ipse B. Harnungus congerere potuit, nec quisquam Ungarorum (proh supinam negligentiam) consignavit. Quidquid proinde respectu pastorum Ungaricorum Coronensium huc adnectimus, ex matricula ecclesiae eiusdem, quam Josephus Szeli, eiusdem ecclesiae 23 annorum minister ex antiquis scripturis erurere potuit, decerpimus. Quoad ecclesias vero praediales per Barciam Ungaro-evangelicas, pastorum seriem a nostri maiorumque memoria, sola ex experientia, seniorumque fidedigna relatione, ita tamen, ut ab ecclesiis inferioribus, ex quibus ad maiores promoti sunt incipientes ad maiores descendamus, subnectimus." Majd Szeli a margóra utólag a következőket jegyezte, megmagyarázva, hogy miért maradt el a barcasági magyar lelkészlisták bevezetése: „Nota bene. Collectum hunc inscripturo catalogum mutuo clarissimus dominus Petrus Clos secum communicari petitum eripuit, neque unquam restituit Josepho Szeli, sed matriculis ecclesiarum inferendo aliena vitula aravit.” Ung. Gesetz-Buch, i. m. 210.

${ }^{33}$ Bonorum Parochialium Capituli Barcensis Inventarium, Ung. Gesetz-Buch, i. m. 218-236. 
in Arndt Zeit zu halten” ${ }^{34}$ és az ehhez kapcsolodó „Transactiones cum Vectoribus ante Contractu(m) Decimarum habendae." ${ }^{35}$ A Szeli által átvett következö szöveg szintén egy szabálygyüjtemény, amelyet 1606-ban állítottak össze. Ennek csupán első nyolc tétele érdekelte a magyar prédikátort, amely az egyházi és a világi hatóságok egymáshoz való viszonyát szabályozza és megállapítja, az év milyen napjain tilos dolgozni. ${ }^{36}$ A többi huszonnégy, a tizedről szóló tételt kihagyta, megjegyezve viszont, hogy ezeket már lefordította és elmondta prédikációban/beszédben, viszont nem hivatkozik semmilyen írásra. ${ }^{37}$ Kihagyta „Egy bába eskütételét" 38 és befejezi másolatát a brassói plébániának tett pénzbeli adományaival, ebből a régi és új szokás szerint megszabandó személyzeti járulékokat kiszámítva. ${ }^{39} \mathrm{Az}$ új módszer szerinti átszámolás hiányzik Harnungnál, aki viszont a plébánosnak járó összegeket utolsóként jegyezte fel. ${ }^{40}$ Ezt előzi meg egy, a plébános életére, annak küzdelmeire vonatkozó fél oldal, amelyet Szeli a példányának címlapjára másolt be. ${ }^{41}$

Harnung szöveggyüjteményét követi David Hermann (†1682) nagybaromlaki lelkésznek ${ }^{42}$ az Approbatae Constitutiones-böl, az Erdélyi Fejedelemség először 1653-ban, Gyulafehérvárott megjelent törvénygyüjteményéböl készített kivonatos latin fordítása (,Approbatarum Constitutionum Regni Trannsilvaniae Annexarumque Partium Hungariae ... Systema ..."; 255-302), amely az eredeti münek csak azon cikkelyeit tartalmazza, amelyek a szászok jogaira és vallásgyakorlatára vonatkoznak. Ennek a kéziratnak fennmaradt egy 19. századi másolata, amelyet a Fekete templom levéltárában orriznek, ${ }^{43}$ és amely sokkal rövidebb, mint a kötetünkben szereplő, egyébiránt szintén (II.) Szeli József által bemásolt szöveg. Míg az utóbbi minden cikkelyt legalább egy összefoglaló mondatban rögzít, addig a későbbi másolat csupán ezek megnevezését tartalmazza. Szeli átvett magyar szövegeket az Approbaták 1696-os kolozsvári kiadásából, mint például I. Rákóczi Ferenc hivatali esküjét: „Conditiones Celsissimi Domini, D(omi)ni Francisci

\footnotetext{
${ }^{34}$ AH, I.F.66, 152-166.

35 AH, I.F.66, 167-168.

${ }^{36}$ Ung. Gesetz-Buch, i. m. 250-251.

37 „Reliqui 24. Articuli de Decimis sonantes mea opera Ann(o). 17 in Ungaricum sermonem conversi videntu pag." Ung. Gesetz-Buch 250.

38 „Eyd einer Hebammen” AH, I.F.66, 183-184.

39 Ung. Gesetz-Buch, i. m. 252-253.

40 AH, I.F.66, 195-196

${ }^{41}$ AH, I.F.66. 194; Ung. Gesetz-Buch, i. m. 173.

42 David Hermann (†1682) Medgyesen született, ahol városi jegyzőként kezdte pályafutását. 1648-tól Egerbegyen lelkipásztor, majd 1668-tól Nagybaromlakon. Több egyháztörténeti írása kiadatlan maradt. Trausch, Joseph, Schriftsteller-Lexikon der Siebenbürger Deutschen, Bd. II, Köln, Wien, Böhlau Verlag, 1983 (Schriften zur Landeskunde Siebenbürgens, 7/II), 121-124; SzEGEDI Edit, Geschichtsbewusstsein und Gruppenidentität: die Historiographie der Siebenbürger Sachsen zwischen Barock und Aufklärung, Köln, Weimar, Böhlau Verlag, 2002 (Studia Transylvanica, 28), 399-404; WAGNER 1998, i. m. 203.
}

${ }^{43}$ AH, IV.F.1.Tf.12.II.III/23, 405-420. 
Rákotzi." ${ }^{\prime 4}$ A többi fejedelem esküjét nem is említi. Ezen kívül találkozunk még két más magyar szövegrésszel, valamint a rendek közötti uniók eskütételével. ${ }^{45}$ A másolat végét a váltólevelek szabályozása (limitatio litterarum redemptionis) és egy betürendes index foglalja el, amelyet az utolsó oldalon pár sornyi, a szász papok jogait illető kivonat követ a Werböczi-féle Tripartitumból.

A következő húsz oldalon (303-323) találjuk Hajdú István saját kezü családi krónikáját „,Születésről, Házasságrol Temetésről és egyéb emlékezetes dolgok(na)k rövid feljedtzése" címmel. A szöveg id. Hajdú István brassói magyar pap halálával (1694. december 12.) kezdődik, és 1748. március 10-zel zárul. Tartalma többnyire családi eseményekből áll, de találunk köztük politikai és egyházi jellegü adatokat is. Példának okáért közlünk egy pár szemelvényt:

A(nn)o 1714, Mense Nov(embris). Takarodot által a Bartzán a Svetiai király kevés számu Hada ugymint 1500, kikis Benderböl avagy Török Országbol kijövén Erdélyen által magok Országokba sietvén elmentek ... A(nn)o 1716 Men(se). Decemb(ris). Vették el a Nimetek a Magyar Templomunkot az Obrassai kapun belöl ... A(nn)o 1718 4. Aug(usztus). Estve 8 ora tájban Eget el a Szent János Temploma, az Ispotályos Templom, a Bolonnyai kapu, sok Várbeli épületek Bolonnya nevü Hostáttyaval egyetemben ... A(nn)o 1718 2da oct(obris) Takarodot ki a Városbol a Városi Nép a Pestis elől ... ${ }^{46}$

1751-től 1761-ig (II.) Szeli József folytatta ezeket a krónikaszerű feljegyzéseket, amelyek azonban már kizárólag személyes és családi jellegüek.

A kódex 324. oldalán ismét Hajdú kézírásával találkozunk, aki Magellán, Vespucci és Kolumbusz felfedezéseiről másolt be szöveget, valamint, arról, hogy „Drága szerszámoknak nemei hol és micsoda hellyen terem Indiában.” A következő két oldalon (325-326) található a közleményünk címében is szereplő két ismeretlen Báthori Gábor kori vers, amelyeket szintén Hajdú másolhatott be. (L. 2. függelék.) Erről alább bővebben fogunk szót ejteni. Ezt követi négy utólag bekötött, oldalszámozás nélküli lap. Az első kettőre a „Világ Teremtése után a Christus születésekor irtak 3962 Esztendőben már a Christus születésétől fogva lettenek ezen aláb meg írt dolgok" címü bejegyzés olvasható, amely üdvtörténeti, világtörténeti és magyar történelemből vett eseményeket jegyez fel időszámításunktól 1558-ig. Ez is Hajdú keze munkája. Az utolsó két beillesztett lap három oldal terjedelemben Hajdú István életrajzát tartalmazza (1. függelék), amely minden bizonnyal a temetésére készült el, a gyászbeszéd részeként, mivelhogy az utolsó mondatban a porkoláb elbúcsúzik a hallgatóságtól, megkérvén, hogy tisztességesen temessék el. Ennek írnoka - és minden bizonnyal szerzője is - az elhunyt veje, (II.) Szeli József brassói magyar evangélikus lelkész.

${ }^{44}$ Ung. Gesetz-Buch, i. m. 259-262.

${ }^{45}$ Ung. Gesetz-Buch, i. m. 268-269.

${ }^{46}$ Ung. Gesetz-Buch, i. m. 305-306. 
Ahogy azt a fentiekben láthattuk, a vegyes tartalmú kötet sok értékes forrást rejt, különösen a barcasági magyar evangélikusok történetét illetően. Legnagyobb kincse azonban kétségkívül az a két ismeretlen régi magyar vers, amelyet Hajdú István a kötetbe bemásolt. A törcsvári porkolábnak a költészet iránti érdeklődése egy apró adat alapján eddig is világos lehetett. 1911 óta tudjuk, hogy egy ideig az ö birtokában volt a később Csereyné-kódex néven ismert 16. századi kézirat, az egyik legrégebbi magyar nyelvü verseskönyv, amelyet ma sajnos csak a szakirodalomból ismerünk, mert 1945-ben a Székely Nemzeti Múzeum többi menekített anyagával együtt elpusztult. ${ }^{47}$ Hajdú Szegedi Andrásnak és Tinódi Lantos Sebestyénnek egy-egy itt szereplő versét (Jeruzsálem veszedelméről, 1558., ill. Iaszón király históriája, 1566) a forrásszövegek alatt saját kora helyesírásával átírta, mert úgy ítélte meg, hogy a régies, már-már „szkítiai” írást más nem tudja majd elolvasni. Számos hibával terhelt másolata végére büszkén a saját nevét és a dátumot (1741. október 4.) is odabiggyesztette. ${ }^{48}$ Elképzelhető, hogy nem csak a Csereyné-kódex, hanem egy másik, 17. századi gyüjteményes kötet is a birtokában volt, és abból másolta ki a nagysinki kötetben szereplö két verset, sajnos azonban semmiféle támpontot nem ad a szövegek eredetét illetően.

A két vers föszereplöje szokatlan módon nem más, mint egy híres fegyver, az úgynevezett Farkas-ágyú, amelynek történetét Kovács András 2007-ben külön tanulmányban dolgozta fel. ${ }^{49}$ Mivel azonban a müvészettörténész gyüjtését több alapvető jelentőségü forrással is bővíteni tudtuk, úgy döntöttünk, hogy nem lesz felesleges az ágyúra vonatkozó információkat újra összefoglalni.

Bevett szokás volt az a kora újkori Magyarországon, hogy az ágyúknak állatneveket adtak. Farkas nevü löveggel számos várban találkozunk: 1555-ben Gyulán, 1669-ben pedig Huszton. ${ }^{50}$ Ezeknél azonban ismertebb egy irodalmi példa: Zrínyi Miklós eposzában, a Szigeti veszedelemben (1645/1646) a magyar oldalon szerepel ilyen névvel egy hatalmas ágyú, amellyel Szulejmán érkezésekor Csontos Pál a török seregbe lö, nagy pusztítást végezve a pogányok soraiban. ${ }^{51}$

A leghíresebb Farkas-ágyú azonban kétségkívül az a löveg, amely az Erdé-

47 Dézsi 1911, i. m. 59. Stoll Béla, A magyar kéziratos énekeskönyvek és versgyüjtemények bibliográfiája (1542-1840), Bp., Balassi Kiadó, 2002, 23. (No. 1.)

48 „Ezen feljebb megírt szkítiai írásokat, melyet nem minden keresztény olvasó tudna elolvasni, fordította új betükre Brassóban, bolonyai hóstátban lakó Hajdú István, a törcsvári castellanus in anno 1741, die 4. octobris” Dézsi 1911, i. m. 59. Binder Pál monográfiájában a „szkítiai írás” (= régi korból való írás) kifejezést félreérti, és tévesen azt feltételezi, hogy Hajdú István a rovásírás megfejtésével foglalkozott. BINDER 1993, i. m. 60.

${ }^{49}$ Kovács András, „Farkas az én nevem....” A gyulafehérvári fejedelmi fegyvertár és ágyúöntés kezdeteinek történetébe. = Dolgozatok az Erdélyi Múzeum Érem-és Régiségtárából, 2(2007), 157-172.

50 KarÁcsonyI János, Békésvármegye története, I. köt., Gyula, Békésvármegye, 1896, 157. KonCz József, A huszti vár lövő szerszámainak leltára = Hadtörténelmi Közlemények, 5(1892), 133-140.

${ }^{51}$ „Meghagyá Zrínyi Miklós pattantyúsoknak/ Ágyúból köszöntést töröknek adjanak./ Legelső Csontos Pál egy végét kanotnak/ Gyújtólikához tevé Farkas ágyúnak. - Gyorsan rettenetes pattantyú kisüle,/ Török tábor felé golyóbisát küldé,/ Az láthatatlan sereg közé jüve,/ Rettenetös halált 
lyi Fejedelemség legnagyobb méretű és legdíszesebb lőfegyvereként vonult be a hadtörténetbe. Nem kizárt, hogy a költő Zrínyit is éppen ez a különleges tárgy ihlette egy hasonló ágyú szerepeltetésére. Az erdélyi Farkas ágyút Báthori Zsigmond fejedelem öntette 1593. április 2-án, a gyulafehérvári ágyúöntőházban. ${ }^{52}$ Az ágyú feliratait ugyan Szamosközi István is leírta, ám a legpontosabban a történeti érdeklődésű Conrad Jacob Hiltebrandt örökítette meg, 1656. évi útinaplójában. ${ }^{53}$ Innen derül az ki, hogy a löveget a segesvári Jeremias Aurifaber tervezte, és a salzburgi Mauritius Haas öntötte, ${ }^{54}$ 1593-ban, amikor Almási Albert volt a fegyvertár vezetője.

Kovács András Szamosközi István és Szalárdi János - egymásnak számos pontos ellentmondó - adatai alapján az ágyú méretének megbecslésére is vállalkozott. Eszerint a fegyver körülbelül hét méter hosszú lehetett, külső átméröje pedig a lőporkamránál (a tárgy legszélesebb pontján) 62,2 centimétert tett ki. ${ }^{55}$ Súlya a szerző szerint akár a tíz tonnát is elérhette. A fenti adatok alapján a Farkas a hosszabb csövü, de kisebb kaliberü tábori ágyúk és a rövid csövü, tömzsi faltörő ágyúk szokatlanul nagy méretben megvalósított házasítása lehetett.

Nemcsak mérete tette azonban különlegessé, hanem díszítése is, amelyet a legpontosabban Bethlen Farkas Szamosközi szövegét további információkkal

ő közikben vive.” ZRíNYI Miklós összes müvei, szerk. Kovács Sándor Iván, Bp., Kortárs Könyvkiadó, 2003, 105. (VII. ének, 21-22. vers.)

${ }^{52}$ 1593. ápr. 2. „Tormentum ingens Lupus fusum est.” SzAmOSKÖZI István történeti maradványai, kiad. Szilágyi Sándor = Történelmi Tár, 1889, 33.

53 SzAmosközy István történeti maradványai 1566-1603, II, (1603), kiad. Szilágyi Sándor, Bp., MTA, 1877 (Monumenta Hungariae Historica Scriptores, 29), 146-148. - Conrad Jacob Hiltebrandt (1629-1729) stettini születésü teológushallgató volt, aki először 1656-ban járt Erdélyben, Gotthard Welling és Heinrich Coelestinus von Sternbach svéd követek kíséröjeként. A Farkas-ágyúról így ír: „Auff der Schloßmauren stand ein schön groß Metallen Stück, Lupus genand, darauff folgende Schrifft zu lesen war: 1593/ Hieremias Aurifaber, Schegeswariensis Inventor./ Sigismundus Batori, Princeps Transylvaniae et Siculorum Comes./ A. D. 1593./ (insignia principis)/ Legibus et Reipublicae/ Sum Lupus, alpinum nomen ne temnito lector,/ Nata est auspiciis incylta Roma meis./ In tempore Alberti Almasi, tormentorum Praefecti/ Mauritius Has Saleburgensis me fudit./ Exurgat Deus et dissipentur inimici eius." Conrad Jacob HiLteBrandT's Dreifache Schwedische Gesandtschaftsreise nach Siebenbürgen, der Ukraine und Constantinopel, Hrsg. Franz Babinger, Leiden, E. J. Brill, 1937, 50. Hiltebrandt erdélyi tartózkodásairól: KÁRMÁN Gábor, Egy teológushallgató találkozása a felekezeti sokszínüséggel, Conrad Jacob Hiltebrandt Erdélyben, 1656-1658=Korall, 57(2014), 28-29.

${ }^{54}$ A Szamosközi István szerint csaknem törpe (paene pumilio) Mauritius Haas származási jelzője (Salzburgensis) okoz némi fejtörést, hiszen Erdélyben is volt egy Salzburg, a Szebenhez közeli Vízakna. Szamosközi szövege alapján mégis valószínűbb, hogy a hangsúlyozottan erdélyi (Transylvanus) Jeremias Auriberrel ellentétben Mauritius Haas külföldi származású volt.

55 Kérdés persze, hogy Kovács András a meglehetősen homályos, más latin szövegekben nem előforduló ,ambitus crassitudinis” (= a vastagság kerülete) kifejezést jól értelmezi-e, és Szamosközi nem tévedésből írt-e az átmérő helyett kerületet. Az ágyúnak a mủvészettörténész által kiszámolt külső átmérője talán túl kicsi a feltételezett kaliberhez. Nyilvánvaló ugyanakkor, hogy a kérdés teljes bizonyossággal nem dönthető el. 
kiegészítő 17 . századi leírásából ismerünk: ${ }^{56}$ az ágyú testét dombormüves figurális díszítés borította. A kompozíció mértani középpontjában egy trónon ülő oroszlán, mint az állatok királya helyezkedett el, akit létező és mesebeli teremtmények egész hada vett körül: vízilovak, szirének, medúzák, kígyók, madarak. Szintén valahol az ágyú oldalának középső harmadán kaphatott helyet a Báthori-család farkasfogas címere. ${ }^{57} \mathrm{~A}$ torkolat körül egy zsoltáridézet húzódott: „Fölkél az Isten, elszélednek ellenségei" (Zsoltárok 68:1), amelyet a latin bibliafordításban szereplő felszólító mód (,széledjenek szét”) még hangsúlyosabbá tett. Az ágyú hátsó részét egy mellső lábaira támaszkodó, vicsorgó, harapásra kész farkas fél alakja foglalta el, nyakán szöges nyakörvvel. Lent a gyújtólyukat medúzafó vette körül, az ágyú tetejére pedig egy irányzékul is szolgáló kölyökfarkas került. A müvészi dombormúveken, illetve a megrendelöre és kivitelezőkre vonatkozó feliratokon kívül fontos részét képezte a külcsínnek a humanista udvari költő, orvos és diplomata, Hunyadi Ferenc $(\dagger 1600)$ egy verse is. ${ }^{58}$ A disztichonos epigrammában maga az ágyú szólította meg az olvasót. „Én vagyok a Farkas. Ne vesd meg, olvasó, hegyvidéki nevezetemet, vezérletemmel született meg a híres Róma.” („Sum Lupus, alpinum nomen ne temnito, Lector/ Nata est auspiciis inclyta Roma meis") A névadás alapjául szolgáló farkasfogas címeren és a nagy figurális dombormúvön túl tehát egy költemény is egyértelmüvé tette, hogy a löveg milyen állatot testesít meg. A Romulust és Remust tápláló római anyafarkas és az antik Róma dicsősége a tárgy szimbolikája révén áttételes kapcsolatba ke-

56 „Totum corpus anaglyipticis sculpturis, exstantibusque palmarum atque florum formis, itemque ad similitudinem expressis hippopotamorum, sirenum,medusarum, serpentum, volucrum, ementitisque aliarum animantium figuris, itemque omnium ferarum, in unum locum Leone in throno sedente, ac eis praesidente, confluxu mirifice exornatum atque excultum. Prorsus, ut non immerito inter fusiles celeberrimi operis veterum statuas accenseri cooptarique possit, cui Lysippus et Polycletus invidere possint, tam insigne opus e sua officina non prodiisse. Circa orificium, ubi globos evomebat, tali circumscriptione insignitum fuerat: „Exurgat Deus, et dissipentur inimici ejus.” In posteriori vero machinae parte Lupus semisse sui, cum capite et anterioribus pedis emergens, ringente ore, dentibusque frendentibus ac morsum minitantibus, collo millo ornatus visebatur. Foramine, per quod pulvis pyrius succenditur, os capitis medusae cujusdam vires subibat, in superiori vero tergore tormenti finem versus pro indice collimatorio catellus lupinus jacebat.." Az álló betükkel szedett részek Szamosközitől származnak, míg a dőlt betüsek Bethlen Farkas saját kiegészítései. Wolffgangi de BETHLEN celsissimi principis Transsylvaniae consiliarii intimi, supremi comitis comitatus Albensis, nec non regni cancellarii historia de rebus Transsylvanicis, Tomus V (Lib. XI-XII.) Cibinium, Martin Hochmeister, 1789, 263-264. - Kovács András e leírásnak csak azt az erősen töredékes magyar változatát ismerte, amelyet Bethlen Farkas Szamosközi István kéziratába vezetett be: SzAmosKöZi 1877, i. m. 146-147.

${ }_{57}$ A farkasfogas Báthori-címerről: SzEKeres Attila István, Címerében három farkasfog $=$ Müvelödés, 56(2013), 3, 13-17.

${ }^{58}$ Hunyadi Ferenc költészetéröl: Tо́тн István, A gyulafehérvári latin nyelvü humanista költészet alapvonásairól = Irodalomtörténeti Közlemények, 105(2001) 1-2, 19-20; TóTH István, A gyulafehérvári humanista költészet antológiája, „Költök virágoskertje”, Bp., Accordia Kiadó, 2001, 360-362, 435. 
rült a Báthori nemzetséggel, és éppen ez a cél lebegett az alkotók szeme előtt. Ahogy azt Szamosközi is hangsúlyozza, a Farkast nem azért öntötték, hogy csatákat vagy várostromokat döntsenek el vele. Díszfegyver volt, amely a Báthoridinasztia erejét és elszántságát reprezentálta. A fiatal, éppen a török elleni harcra készülő Báthori egy évvel később, 1594-ben könyörtelenül „szét is szélesztette” ellenzékét, kivégeztetve mindenkit, aki nem értett egyet a török háborúba való belépéssel.

A Farkas egész létezése során díszfegyver maradt, nagy súlya miatt csak igen ritkán mozgatták. Állandó jelleggel a Kendervárnak nevezett gyulafehérvári fegyvertárban őrizték, 1627-től aztán a hadszertár újonnan elkészült olaszbástyájára vonták fel, amelyet a szász natio épített a város délkeleti sarkán. ${ }^{59} 1656$-ban Conrad Jacob Hiltebrandt is a város falán látta a pompás fegyvert.

1603-ban ugyan Székely Mózes hadvezére, Borbély György azzal fenyegette a szászsebesieket, hogy városuk ostromához felvonultatja a Farkast, de a krónikás szerint a polgárok a bevetés puszta hírére megadták magukat, és az ágyú a hadszertárban maradt. ${ }^{60} 1660$ elején, az erdélyi polgárháború egyik csúcspontján azonban II. Rákóczi György egy hasonló fenyegetést beváltott, a Gyulafehérvár 1658. évi pusztulásakor megsérült, és szerelékeit vesztett ágyút a Segesváron készített új állványra és szántalpakra helyezte, és Szeben ostromához vitette. ${ }^{61} \mathrm{Az}$

${ }^{59}$ KovÁcs 2007, i. m. 162. A korábbi parttalan etimologizálásokat cáfolva Kovács András tisztázta azt, hogy a Kendervár minden bizonnyal a városerődítés kenderáztatásra is használt árkáról kapta nevét. - A szász nemzet bástyájáról: Erdélyi országgyülési emlékek, 8, kiad. Szilágyi Sándor, Bp., MTA, 1882, 71.

${ }^{60}$ SzAmosKÖZI 1877, i. m. 148.

${ }^{61}$ Az ágyú utolsó, 1660. évi kalandjának Kovács András által is használt forrásai: SzALÁRDI János, Siralmas magyar krónikája, kiad. Szakály Ferenc, Bp., Magyar Helikon, 1980, 524-525; Georg Kraus, Erdélyi krónika 1608-1666, kiad. Vogel Sándor, Csíkszereda, Pro-Print, 2008. A müvészettörténész által nem ismert és nem idézett két forrás: (1.) KereszTúri Demeter, Acta dierum, sub quibus illustres principes, Georgius Rakoci et Achatius Bartsai una cum suis adhaerentibus intra et extra civitatem Szeben super regimine regni Transylvaniae contendunt, ANDJS Col. Brukenthal B 1-5. No. 46. f. 33v., 55r, 77v., 83v., 99v. A mü a 19. században nyomtatásban is megjelent (Archiv des Vereins für Siebenbürgische Landeskunde, 19(1884), Heft 1, 127-223, Heft 2, 228-325.) mivel azonban ez a magyar szövegrészeket német fordításban közli, a pontosság miatt inkább az eredeti kézirat használata mellett döntöttem. (2.) SEIVERT, Johann, Die Provinzialbürgermeister zu Hermannstadt in Grossfürstenthum Siebenbürgen, II.= Siebenbürgische Quartalschrift, 2(1791), 3, 235-306. Benne Paul Prefling szebeni polgár naplójának kiadása (277-306.) - Két jellemző részlet Keresztúri művéből: 1660. jan. 31. Tárgyalások Rákóczival annak sellenberki tábori országgyülésében. „Haec dum aguntur, advesperascit, interim notandum, quod inter egregios haustus in mensa Rakociana volvuntur lepida jocoseria colloquia [...] Incidenter cum Rakocius diceret: „No, harmadnap alatt elérkeznek a Farkassal.” (Vocatur enim quoddam generosissimum tormentum Albae Iuliae habitum Farkas.) Ad haec dicit Ugron /András/: Ha a medvét is elhozatja nagyságod, de mi azzal nem sokat gondolunk, a’ Nyúl is azon völgyön szokott veszni, a hol fiadzik.” f. 55r. 1660. márc. 5. Visszajön Sellenberkről, II. Rákóczi György táborából Matthias Deák, és beszámol a fejedelemmel folytatott beszélgetéséről. „Mondá azt is őnagysága, hogy Segesváratt csinálják az Farkas álgyúnak az agyát, kerekeit.” f. 77v. - Érdemes megjegyezni, hogy Keresztúri 
ostromsáncig Keresztúri Demeter szerint negyven ökör, a segesvári Georg Kraus szerint pedig nyolcvan pár ökör húzta el a monstrumot, amely 1660. március 18án érkezett meg. ${ }^{62}$ Március 22-én azonban már el is indították vissza Szászsebes felé, mert lövései nem érték el a kívánt hatást. ${ }^{63}$ Szalárdi János úgy tudja, hogy az ágyút a gyújtólyuk sérülése miatt nem is merték teljesen megtölteni. A kirándulás végzetes következményekkel járt a lövegre nézve. Az ágyú talpát (lafetta) a szebeniek a sikertelen ostrom végeztével, május 15-én a várostól néhány kilométerre nyugatra fekvő Kistoronyban találták meg, a többi sáncban hagyott hadiszerrel együtt. ${ }^{64}$ Maga az ágyú egy oroszcsüri paraszt 1660. április 27-i beszámolója szerint egy darabig Apold mellett, tehát félúton Nagyszeben és Szászsebes között vesztegelt. ${ }^{65}$ Paul Prefling krónikástól pedig megtudjuk, hogy a Farkast valamikor június elején Szászsebesből Szebenbe vitték, ahol a városi tanács utasítására szétfürészelték, és anyagából kisebb ágyúkat öntöttek. ${ }^{66}$ Ez utóbbi információ ugyan csak nála szerepel, ám valószínúleg hitelt érdemlő. Az ágyú tehát nem török kézre került 1660-ban, ahogy azt Kovács András feltételezte, hanem a szászok szerezték meg, és a szimbolikus politizálás gyülölt eszközét rövid úton megsemmisítették.

Nem ez volt azonban az egyetlen alkalom, hogy az ágyú Szebenben járt. Bár a legtöbb egykorú krónikás, és ennek nyomán a nagy történeti összefoglalások is hallgatnak az esetről, ${ }^{67}$ a marosvásárhelyi Nagy Szabó Ferenc $(* 1581)$ elbeszé-

Georg Kraus és Szalárdi János szövegével ellentétben következetesen kerekekröl beszél.. Mivel tél közepén történt a szállítás, hajlunk rá, hogy talán még is inkább szántalpakról lehetett szó, ahogy azt a másik két krónikás írja.

${ }^{62}$ ANDJS Col. Brukenthal B 1-5. No. 46. f. 83v.

63 1660. márc. 22. „Den 11ten geschahen 3 Kanonenschüsse, doch ohne Schaden. Auch hatten wir den schreklichen Wolf nicht mehr zu fürchten, denn weil er die gehofte Wirkung nicht that, wurde er nach Mühlenbach abgeführt." SEIVERT 1791, i. m. 295.

64 1660. máj. 15. „Nun lief alles Volk hinaus, zerstörte die Schanzen und machte Beute, zu Neppendorf fand man die Lavetten vom Wolf..." SeIvert 1791, i. m. 304,

65 „Apoldon túl találék egy álgyút is az útban, de veszteg áll vala, és én távol kerülém. Az parasztemberektől úgy értettem, hogy az Farkas álgyú, és Szászsebesbe viszik etc.” ANDJS Col. Brukenthal B 1-5. No. 46. f. 99v.

${ }_{66}$ 1660. máj. 30. „Den 30ten wurde eine schöne Kanone, welche von den Feinden im Nependorfer Grund zurück gelassen, hereingebracht. Nach etlichen Tagen kam auch der grosse Wolf von Mühlenbach an, welchen der Rath zersägen, und kleinere Kanonen daraus giessen lies, damit er nicht einmal könnte zurück gefordert werden." SEIVERT 1791, i. m. 305.

${ }^{67}$ A szállítást nem említő korabeli történeti munkák közös jellemzője, hogy az 1612. év kapcsán a nagyobb eseményekre, különösen a brassóiakkal folytatott barcasági harcokra koncentrálnak: Casparis Bosthini Pannonii de rebus gestis magni Gabrielis Bethlen librorum duodecim inchoatorum libri tres = Monumenta Ungrica, ed. Johann Christian Engel, Vienna, Antonius Doll, 1809, 237-436; HídvÉGi Mikó Ferencz historiája a maga életében történt erdélyi dolgokról 15941613, kiad. Kazinczy Gábor, Bp., MTA, 1863 (Monumenta Hungariae historica, Scriptores, 7), 135-304; SzEPSI LACZKó MÁTÉ, Lorándffi Mihály udvari concionatora krónikája és emlékezetre méltó hazai dolgoknak rövid megjegyzései 1521-1624 = Erdélyi történelmi adatok, III, kiad. Mikó Imre, Kolozsvár, Ev. Ref. Főtanoda, 1858, 1-246. Az egykorú szász történetírók (jellemzően bras- 
léséből és Gyulafehérvár város jegyzőkönyveiből tudjuk, hogy az ágyút Báthori Gábor erdélyi fejedelem (1608-1613) is Szebenbe vitette, méghozzá 1612-ben, és csak Bethlen Gábor szállítatta vissza a Kendervárba, nagyjából egy időben azzal, hogy telelése után 1614 . február 18 -án végleg elhagyta a szász várost. ${ }^{68}$ Éppen Báthori akciójáról, erről a jelképes jelentőségü eseményről szól a Hajdú István kötetéből előkerült két ismeretlen költemény. A versek címéből az is kiderül, hogy pontosan 1612. augusztus 25-én érkezett meg az ágyú a városba. A löveg mozgatásának, ahogy 1660-ban, úgy ekkor is propagandisztikus célja volt: a fejedelem így akarta hatalmát demonstrálni a politikai törekvéseivel szemben ellenséges szászoknak. A történeti háttér jól ismert. ${ }^{69} 1610$. december 12-én Báthori Gábor hadicsellel elfoglalta Nagyszebent, amelyet a tizenötéves háborúban félig elpusztult Gyulafehérvár helyett, a szászok hagyományos autonómiáját semmibe véve, székvárosává tett meg. A fejedelem közben fegyveres konfliktusba került Radu Şerban havasalföldi vajdával, Forgách Zsigmond felső-magyarországi főkapitánnyal (1611), ${ }^{70}$ és saját tanácsosainak jelentős részével is megromlott a viszonya. Michael Weiß vezetésével a brassóiak már 1611-ben fellázadtak Báthori ellen, és 1612-ben szabályos polgárháborút folytattak a fejedelem csapatai ellen, de egyre inkább védekezésbe szorultak: éppen augusztus utolsó heteiben már Brassó falai alatt dúlt a harc. A küzdelem csak a brassóiak 1612. október 16-i barcaföldvári veresége után csitult valamelyest. Báthori fejedelmi székére 1612-ben már egy komoly belső ellenfél is pályázott, Géczi/Giczi András. Mintegy másfél héttel a szállítás elött, 1612. augusztus 12-én ölte meg

sóiak) szintén nem tesznek említést a Farkas-ágyú költöztetéséről. Munkáikat főként a következő forrásgyüjteményekben találjuk meg: Deutsche Fundgruben der Geschichte Siebenbürgens, Bd. I-II, Hrsg. Kemény József, Klausenburg, Verlag von J. Tilsch, 1840; Bd. III, Hrsg. Eugen von Trauschenfels, Kronstadt, Druck und Verlag von Johann Gött, 1860; Quellen zur Geschichte der Stadt Brassó, Bd. IV, Chroniken und Tagebücher I (1143-1867), Brassó, Druck von A. Gust. 1903.

${ }^{68}$ NAGY SzaBÓ Ferenc memoriáléja = Erdélyi történelmi adatok, I, kiad. Mikó Imre, Kolozsvár, Ev. Ref. Főtanoda, 1855, 103-104; Gyulafehérvár város jegyzökönyvei, Erdélyi történelmi adatok, VI/2, kiad. Kovács András. Kolozsvár, Erdélyi Múzeum Egyesület, 1998, 37-38, 282.

${ }^{69}$ Báthori Gábor szász politikájának néhány ismertebb feldolgozása, időrendben: MiKA Sándor, Weiss Mihály. Egy szász államférfiú a XVII. századból, Bp., Magyar Történelmi Társulat, 1893 (Magyar történeti életrajzok, 24); ANGYAL Dávid, Báthory Gábor uralkodása = Századok, 30(1896), 23-46, 114-128; Teutsch, Georg Daniel, Geschichte der Siebenbürger Sachsen für das sächsische Volk, Bd. I, Von den ältesten Zeiten bis 1699, Hermannstadt, Druck und Verlag von W. Krafft, 1899, 327-348; Lovas Rezső, Báthory Gábor és a szászok, Debrecen, 1940 (A Debreceni Tisza István Tudományegyetem történelmi szemináriumának kiadványai, 8); PHILIPPI, Maja, Michael Weiß. Sein Leben und Wirken in Wort und Bild, Bukarest, Kriterion Verlag, 1982; NAGY LÁszLó, Tündérkert fejedelme, Báthory Gábor, Bp., Zrínyi Katonai Kiadó, 1988; CzIRÁKı Zsuzsanna, Brassó és az erdélyi szászok szerepe Bethlen Gábor fejedelem trónfoglalásában (1611-1613) = Századok, 144(2011), 4, 847-876. - A fejedelem uralkodásáról általában: Báthory Gábor és kora, szerk. Papp Klára, Jeney-Tóth Annamária, Ulrich Attila, Debrecen, Debreceni Egyetem Történelmi Intézete, 2009.

${ }^{70}$ VÖRös Péter, Forgách Zsigmond erdélyi expedíciója 1611-ben = Hadtörténeti Közlemények, 124(2011), 3, 864-887. 
Báthori Gábor Nagy András hajdúgenerálist, aki állítólag levélben ajánlotta fel a fejedelem meggyilkolását az ellenjelöltnek. Végül kevéssel a fegyver utaztatása után, szeptemberben szökött török földre az a Bethlen Gábor, aki aztán 1613-ban az oszmán hatalom támogatásával véget vetett a sokak által gyủlölt Báthori uralmának. 1612 augusztusában az események már elérték drámai tetőpontjukat, de még nem látszott, hogy a forrongó helyzet miként alakul majd. Tipikusan olyan hetek voltak ezek, amelyekben a hasonló jelképes politikai aktusok is a szokásosnál is nagyobb nyomatékot nyertek.

Az ágyú 1612. évi szállításáról a két most megtalált vers hordozza a legtöbb információt - míg egyiknek tárgya a megszemélyesített Farkasnak a Kendervártól való búcsúzása (valedictio bombardae), és az utazás maga, addig a másik a fegyvernek az új helyre való megérkezéséről (introitus bombardae) szól. Az ágyút a fejedelem embere, Szalai Farkas kísérte Nagyszebenbe, akit Báthori egy 1612-ben Kolozsvár városnak küldött levelében „meghitt udvari jámbor szolgájának", azaz udvari familiárisának nevezett, kérve, hogy legyenek segítségére a Farkas ágyú „,szerszámainak” (talán talpának, kerekeinek) elkészíttetésében. ${ }^{71}$ Úgy tủnik tehát, hogy Szalainak már a szállítás előkészítésében is szerep jutott. Az első vers Szalait a Farkas „szárazdajkájának” nevezi, és finoman, elegánsan kihasználja a két név azonosságában rejlő költői lehetőséget is. Talán éppen ezt a verset kell keresnünk annak a Nagy Szabó Ferenc által megörökített anekdotának mélyén is, hogy 1612-ben két Farkas ment be Szebenbe. ${ }^{72}$

Bár a két város (az útvonaltól függően) csak mintegy 70-75 kilométerre fekszik egymástól, de a cél eléréséhez előbb át kellett kelni hajóval a Maroson, majd pedig a néhány közbeeső hegyvonulat miatt jelentős szintet is le kellett küzdeni. A folyón való átkelés nehézségét és veszélyeit a vers játékos formában több versszakon keresztül ecseteli. Nem csoda, hiszen nehéz lehetett akkora hajót találni, amely elbírt ekkora súlyt. Elképzelhető, hogy több sószállító hajót kötöztek össze, és úgy vontatták át a vízen a fegyvert. A kerekekre szerelt ágyút szárazföldön ezúttal is minden bizonnyal ökrök húzták. A két Farkas az első vers leírása szerint a mai foút nyomvonalától északra haladt. A Fehér megyei Drassó és Vízakna érintésével értek végül lassú, akár egy hetet is igénybe vevő utazás után Szebenbe. A szöveg mintha arra utalna, hogy az ágyút a szász városban nem valamelyik bástyán, hanem erődemonstrációként a főtéren (Großer Ring) helyezték volna el. („Tudom bévezetnek Szeben piacára”) Könnyen lehet azonban, hogy rövid közszemle után az ágyú itt is a falra került. A leghatásosabb kétségkívül az lett volna, ha a fejedelem és a katonai potenciáját jelképező hatalmas ágyú egyszerre vonultak volna be a városba. Ezt azonban a lovagló, vagy kocsikon ülő fejedelmi udvartartás és az ökrökkel vontatott löveg eltérő sebességét figyelembe véve, kiinduló hipotézisként sem feltételezhettük. Bár Báthori királyi könyve pont erre az időszakra nagyon foghíjas (az 1612. július 6. és augusztus 29. közötti

${ }^{71}$ Erdélyi magyar szótörténeti tár, III, szerk. Szabó T. Attila, Bukarest, Kriterion Könyvkiadó, 1982, 706.

${ }^{72}$ Nagy Szabó 1855, i. m. 103-104. 
időszakból nem tartalmaz kiadványt), és az Erdélyi országgyűlési emlékekben is van egy nagy lyuk 1612. augusztus és október 7 . között, ${ }^{73}$ más források a segítségünkre sietnek. A fejedelem augusztus 25 -én és 27-én is Gyulafehérvárott volt, ám augusztus 29-én már Szebenből keltezett oklevelet, majd szeptember elején még visszatért egy időre a régi székvárosba, de a hónap többi részét láthatóan a szászok ,vendégeként” töltötte. ${ }^{74}$ Jelenlegi ismereteink szerint tehát úgy tünik, hogy az ágyú Báthori egy hosszabb szebeni tartózkodásának nyitányaként tünt fel a városban. Bár a második vers egy helyütt azt állítja, hogy a fegyvert azért vitték Nagyszebenbe, hogy oltalma legyen a település kőfalainak, aligha férhet ahhoz kétség, hogy az átszállítás sokkal inkább a hírverés céljait szolgálta. Egyrészt nyomatékosította a szász település új, székvárosi szerepkörét, másrészt a belső ellenség megfélemlítésére szolgált. Ahogy azt az egyik verssor („,Legyek magyaroknak segítő dandárja") is kifejezi, ilyen belső ellenségnek számítottak a fejedelem ellen ármánykodó urak mellett maguk az elégedetlen szászok is.

Végül ejtsünk néhány szót magáról a két versről (avagy párversről) is, amelyeket tartalmuk és jellegük alapján egyértelmủen az eseményekkel egykorúaknak kell tekintenünk. ${ }^{75}$ Szerzőjük, ahogy az a hasonló propagandaköltemények körében meglehetősen gyakori, nem nevezi meg magát, sem a szöveg előtt, sem a versföben. A Báthori Gábor uralkodási idejéből fennmaradt erdélyi versek között négy olyan históriás éneket is találunk, amely hasonló határozottsággal áll ki a fejedelem törekvései mellett, a sort kiegészíthetjük egy, a fejedelem halálára írt gyászverssel is. ${ }^{76}$ A szerzőt egyik esetben sem ismerjük, csak feltételezni lehet, hogy a versek a fejedelmi udvarban, valamely müvelt familiáris tollából születtek. Külön érdekességet hordoz számunkra, hogy a legismertebb ilyen vers, a Conspiratio Kendiana szövege éppen egy másik barcasági magyar evangélikus értelmiségi, Tatrosi György énekeskönyvében maradt fenn.

${ }^{73}$ Erdélyi országgyülési emlékek, VI, (1608-1614), kiad. Szilágyi Sándor, Bp., MTA, 1880.

${ }^{74}$ A fenti információk készülő fejedelmi itineráriumunkból származnak. A legfontosabb adatok: 1612. aug. 25. Gyulafehérvár. Levél Beszterce városnak: A Magyar Nemzeti Levéltár Országos Levéltára (A továbbiakban: MNL OL) X 1249. Beszterce város levéltára - Missiles, 1612/No. 35. (444. filmtári tekercs); 1612. aug. 27. Gyulafehérvár. Levél Dóczy Andrásnak: A Magyar Tudományos Akadémia Könyvtára, Kézirattár, Oklevélgyüjtemény, K 340. doboz, No. 1441.; 1612. aug. 29. Szeben. Címeres nemeslevél a rettegi Tóth/Borbély Istvánnak MNL OL F 1. A Gyulafehérvári Káptalan hiteleshelyi levéltára - Libri regii, 12. köt., f. 199r-200r.; 1612. szept. 2. Gyulafehérvár. Levél Beszterce városnak. MNL OL X 1249. 1612/No. 37. (444. filmtári tekercs).

${ }^{75}$ Itt köszönjük meg Csörsz Rumen Istvánnak, Szentmártoni Szabó Gézának és Vadai Istvánnak a versek kiadásához és értelmezéséhez nyújtott tanácsait,

${ }^{76}$ Régi magyar költök tára, XVII. század, 1, A tizenötéves háború, Bocskay és Báthori Gábor korának költészete, kiad. Bisztray Gyula, Klaniczay Tibor, Nagy Lajos, Stoll Béla, Bp., Akadémiai Kiadó,1959. - Az itt kiadott históriás énekek: No. 96. História Báthori Gáboré/ Conspiratio Kendiana (398-428), No. 97. Cantio de Tranyslvania et de consilio paparum contra haydones equitum (428-432), No. 98. Alia historia de iisdem disturbiis (432-440), No. 99. História az Erdélyországnak nyomorúságáról és magyaroknak Báthori Gábor ellen való föltámadásáról (440-451), No. 103. [Báthori Gábor halotti búcsúztatója] (455-459). 
Szövegeinket azonban a többi Báthori-kori propagandaverstől, amelyek azonos hosszúságú sorokból épülnek fel, határozottan megkülönbözteti strófaszerkezete. A szerző itt egy olyan középkori gyökerü énekelt versformát használ, amely Európa-szerte ismert, de a magyar költészetben viszonylag ritka, az ún. Palkó-strófát. ${ }^{77}$ A metrum felépítése ebben az esetben aszimmetrikus, két tizenkét szótagból álló sort egy hat szótagos félsor kötet, az egész versszakot pedig egy újabb tizenkét szótagos egész sor zárja, a rímelést viszont itt is egyszerü bokorrím (aaaa) biztosítja. A most előkerülteket leszámítva összesen kilenc olyan régi magyar verset ismerünk, amelyet ebben a strófában írtak. Ebből hét Balassi Bálint műve - jellemzően szerelmi tematikájúak. Nem egészen szokványos ritmust választott tehát a költő politikai versei számára. Alighanem a strófa erős zeneisége révén akarta fokozni a szövegek hatását. Az első vershez megadott, ismeretlen énekre utaló nótajelzés („Keserves panasza jó Magyarországnak”) ugyanakkor azt mutatja, hogy a korszakban más magyar politikai vers is használta ezt a formát.

A most megtalált két szövegnek nem csupán föszereplöje a Farkas, hanem maga a megszemélyesített ágyú kommentálja bennük átszállítása körülményeit. A vers tehát a prosopopeia eszközével él, amely a korszak magyar nyelvü költészetében leginkább a halottbúcsúztatókban fordul elö, olyan formában, hogy a halott sorban megszólítja hozzátartozóit, barátait, és néhány őszinte szóval mindegyiktől búcsút vesz. ${ }^{78}$ Sokkal ritkább az, hogy a költő egy tárgyat kelt ilyen módon életre. Világos, hogy a prosopopeiának ez a válfaja a latin nyelvủ humanista költészetből származott át a magyar poézisbe. Hunyadi Ferenc egy versében, az ún. Báthori-útinaplóban a megszemélyesített Róma búcsúzik Báthori Andrástól. Háportoni Forró Pál (†1623) egy múvében pedig maga a váradi vár mondja el a Bethlen Gábor építő munkájáról szóló dicséretet. ${ }^{79}$

Az azonban, hogy a megszemélyesített tárgy egy ágyú legyen, egészen szokatlan megoldás. Egy példát azért ismerünk, és ez nem más, mint Hunyadi Ferencnek a Farkas-ágyún látható, fentebb említett epigrammája. (,Sum Lupus...”) A Báthori-kori költő innen merítette az ötletet, és a második, az ágyú Szebenbe érkezésére írott versben egyértelmüen erre is utalt vissza. („Romulus, Remusnak én voltam mind anyja...”) A latin nyelvü mintát idézi meg az a strófa is, amelyben az ágyú „havasi s erdei vad természetéről” (=,alpinum nomen”) van szó. A fenti két versszak akár az epigramma értelmező fordításának is tekinthető, és a következő sorokban természetesen a Báthori-nemzetség és annak címere is feltünik, hogy a római anyafarkas és a dinasztia közötti kapcsolat mindenki számára egészen világos legyen. Bár a költő a két vers számos pontján megcsillantja költői invencióját és finom humorát, a végső üzenet olyan egyszerü, mint egy bot:

77 A Palkó-strófáról mint referenciális versformáról: Csörsz RuMEN István, Az Palkó nótája (Közelitések) = „Mielz valt mesure que ne fait estultie” A hatvanéves Horváth Iván tiszteletére, szerk. Bartók István et alii, Bp., Krónika Nova Kiadó Kft., 2008, 80-89.

78 Szentmártoni Szabó Géza, Balassi búcsúverse és a prosopopeia a XVII-XVIII. század magyar nyelvü költészetében = Irodalomtörténet, 85(2004), 194-199.

79 То́тн 2001b, i. m. 361-362. 
a fejedelem ellenségeinek, különösen a pártoskodó föuraknak, pusztulnia kell. („Az Farkastól lészen szaggatva gyomrotok.”)

A nagysinki kéziratból előkerült két vers több szempontból is nagyon érdekes és izgalmas. Egyrészt felhívja a figyelmünket a barcasági magyar evangélikus értelmiségnek a kora újkori szöveghagyományozásban játszott jelentős, de eddig ritkán hangoztatott, szerepére, másrészt gyarapítja a régi magyar költészet, és azon belül a politikai versek, ritkán bővülő korpuszát, végül pedig megcsillantja a reményt, hogy erdélyi szász gyüjtemények hasonló magyar vonatkozású köteteiből a jövőben további ismeretlen régi magyar versek is elökerülhetnek.

\section{Függelék}

\section{1. \\ Hajdú István törcsvári porkoláb nekrológja $(1748)^{80}$}

Ungarisches Gesetzbuch, a 326. oldal után

Következik belül említett nemzetes Hajdú István törcsvári magyar porkoláb uramnak nemzetségének deductiója, ki is eredetet vett volt

I. Nagyatyjára nézve ama jó emlékezetủ férfitól, nemzetes Hajdú Miklós uramtól, ki életének ifjúságabeli erejét devoveálta volt II. Rákóczi Györgynek, az erdélyi fejedelemnek, fegyverével élvén, mint hív vitéz a maga kenyerét, míg 1657 esztendőben Lengyelországra nagy haddal menvén a fejedelem, $\mathrm{de}^{81}$ megverettetvén, szerencsétlen viadala után fegyveres vitézi elszéledének, és ugyanakkor említett Hajdú Miklós uram is, mint erdélyi szász famíliából való személy, ${ }^{82}$ Brassóban verekedvén, Türkösben megtelepednék, 40 esztendeig dicséretesen viselvén a türkösi fónagyságot, és nemzvén ottan két fiakat, Jánost és Istvánt.

II. Ezen István nevü gyökérből vett eredetet ezen nemzetes Hajdú István ${ }^{83}$ porkoláb uram is, mert említett Hajdú Miklós uram a fiát, Istvánt a tisztességes tudományokban felnevelte, és az Isten kegyelméből azt is megérte, hogy ezen fia anno [ $]^{84}$ a brassai magyar Sionban lelkipásztori tisztességre emeltetnék, és nem-

${ }^{80}$ A függelékben szereplő két forráshoz csak abban az esetben füzünk tárgyi lábjegyzetet, hogyha a bevezető tanulmány az adott helyet nem magyarázza meg. Az 1. szám alatti nekrológot modernizált átírásban közöljük. A 2. szám alatti két versnek mind betúhív átírását, mind pedig modernizált, és a szövegromlásokat javító változatát feltüntetjük, két párhuzamos oszlopban.

${ }^{81}$ Utána áthúzva: „Az erdélyi fejedelem”.

${ }^{82}$ Itt a szerző valószínűleg Hajdú Miklós jogállására gondol, és nem a származására.

83 Utána áthúzva: „Uram”.

${ }^{84}$ Az évszám helye üresen maradt. 
zene Gothárd Mária asszonnyal két csemetéket, anno 1687 mense augusti Istvánt, kinek hideg tetemi előttünk koporsóban zárattak, és anno 1689 mense octobris Krisztinát. Kikben midőn mint házának csillagaiban gyönyörködni kívánna, akkor kezdé homály beborítani fényes napját, egynéhány esztendeig való bújdosása után keserves fogságban jutván, és sok szenvedési után, midőn megszabadult volna, terhes betegsége után anno 1694 . Advent 3. vasárnapján ${ }^{85}$ meghalván és a Klastrom templomban Brassóban ${ }^{86}$ eltemettetvén, siralmas árvaságra maradván István és Mária, két gyermeki.

III. Szorgalmatos gonddal viseltetett mindazáltal Gothárd Mária asszony az árva gyermekekre, mint maga méhéből való rajzásokra, holott nemzetes Hajdú István porkoláb uramat a tisztességes tudományokban Brassóban neveltette, és azután az ifjúnak gyarapodott állapotjához képest az udvarhelyi református oskolában is általadta. De midőn az ifjúnak legnagyobb reménysége volna, akkor fosztá meg Isten az édes anyai gondviseléstől, anno 1703, éppen húshagyó kedden temettetvén az édes anyja asszony ${ }^{87}$ midőn maga távol volna a tudományoknak kincseinek keresése végett. Éppen ezen árvasága csökkentette meg a jeles indulatú ifjat maga szándékában, hogy a tanúság célját ${ }^{88}$ el ne érhetné, hanem csak Brassóban tartatnék tutorság alatt, míg megélemedett állapotjában ${ }^{89}$ Rákóczi Ferencnek zenebonáskodása ellen felséges római császárunk és igaz erdélyi fejedelmünk mellé támadott Frey companiában hazánknak oltalma végett fegyvert fogott, és azt felséges császárunk mellett híven is viselte mindaddig, míg a kurucok zürzavarok lecsillapíttatott, és sok romlásokat szenvedő hazánk felséges császárunk oltalma alatt a békességnek rév partjára érkezett. Itt már felderülvén házasságra célozó ${ }^{90}$ napja, eljegyzé házastársul Bolonyában lakott néhai nemzetes Farkas Dániel uram hajadon leányát, Annát, és ugyan lakodalmi solemnitásit celebrálá anno 1710. die 8. septembris, de midőn mind kedves feleségében, ’s mind

85 1694. dec. 12 .

${ }^{86}$ A Kolostor utcai egykori Domonkos-rendi Szent Péter és Pál templomról van szó, amelynek szentélyét a reformáció után a helyi magyar evangélikusok használták istentiszteleti helyként, míg a templomhajóban városi gabonaraktár müködött. 1713-ban a templomot az evangélikusoktól elvették, és a jezsuitáknak adták. (Később ennek a helyén építették fel 1776 és 1782 között a brassói katolikus plébániatemplomot.) A magyar evangélikusok ezután előbb a szintén belvárosi ispotálytemplomot használták, majd 1718-ban a gyülekezet kiköltözött a magyar külvárosba Bolonyára (Blumenau). Binder 2000, i. m. 136-140, 328 (6. jegyzet) Salontai, Mihaela Sanda, Mănăstiri dominicane din Transilvania, Cluj-Napoca, Editura Nereamia Napocae, 2002, 125-143; HerrmanN 2010, i. m. 13.

87 1703. február 20. Gödri János brassói magyar lelkész feljegyzései szerint a régi bolonyai kőtemplom 1777. évi lebontásakor megtalálták a Hajdúk egy több családtag számára készített sírkövét, amelyen Gothárd Mária temetésének időpontjaként 1703. február 21. szerepelt. BINDER 2000, i. m. 106.

\footnotetext{
${ }^{88}$ Utána áthúzva: ,ne ..........".

89 Utána áthúzott olvashatatlan szó (cca. 6 betü).

90 A szó egy áthúzott, olvashatatlan szó fölé írva.
} 
ettől született magzatjában gyönyörködni akarna, keserves özvegységre marada anno 1711. 3. novembris, minekutána együtt éltek volna 1 esztendő 8 hetek alatt.

Mind első házastársától és mind gyermekitől megfosztatván, másodszori házasságában lépék néhai tiszteletes Budai János brassai magyar prédikátor uram második hajadon leányával, Judit asszonnyal, anno 1712. die 19. junii, kivel együtt élt is szép időt, úgy mint 36 esztendőket és egy hónapot, dies [ $]{ }^{91}$ mely házasságokat az Isten virágzóvá is tette, mert 1713 esztendőben, die 21. junii adott Isten egy János nevü fiacskát és Mária nevü leánykát egyszersmind, kik közül Mária azon esztendőben 1. julii, János pedig anno 1719. die 24. julii meg is holtanak. De ezen szomorúságokban ugyancsak vigasztalást nyújtott az Isten nékiek, mert a mely leánygyermekekkel, Krisztinával ${ }^{92}$ anno 1716 . die 6 . augusti és Rebekával, anno 1720. die 3. octobris az Isten őket szerette vala, azokat az Isten nagy örömökre meg is tartotta, Krisztinát e' mi magyar gyülekezetünknek papja mellé. Rebekát pedig egy tisztességbéli ötves mesterember mellé plántálván, és őket drága magzatokkal megszaporítván.

IV. A mi pedig belül említett nemzetes Hajdú István porkoláb uram tisztségét illeti, minekutána a zenebonás kuruc vérontásnak vége lett volna, megtelepedvén Brassó városában, a brassai tekéntetes és nemzetes bíráknak önként való gratiájokban állíttatott a város szolgálatjára anno 1710. 13. iulii, melyet midőn viselt volna $16^{93}$ esztendeig egynéhány nap híján, a társaságnak egyező akaratjából a városi szolgáknak öreglegényekké tétetett, és ezen tisztségét tisztességesen viselte 8 esztendeig 4 hónapig. Tekéntetben vette pedig a brassai tekintetes nemes tanács jó szolgájának hívségét, és anno 1735. die 17. octobris hivatalt adott a törcsvári magyar porkolábságra, melynek törvényes confirmatiója és homagialis beiktatása végett méltóságos gróf hallerkői Haller János ${ }^{94}$ úr őexcellentiájához, ${ }^{95}$ erdélyi gubernátor és a felséges ausztriai háznak actualis intimus consiliariusához el is küldötte, confirmáltatta, beeskettette, és azon tisztségben béléptette. Mely tisztségét 12 esztendeig és 3 hónapokig nagy fidelitással viselvén, minekutána hosszas betegségei erőt vévén, ellankasztották volna, lelkét Jézusának ajánlá anno 1748. die 27. februarii reggeli három órakor. ${ }^{96} \mathrm{Ki}$ is utolsó búcsúját vészi tőletek, és e' mai napon kívánja, hogy az siralom cserfája alá tisztességesen tetemét eltemessétek etc.

${ }^{91}$ A konkrét nap helye üresen hagyva. A mellé behúzott függőleges vonal valószínűleg nem egyes.

${ }^{92}$ Utána áthúzva: „őket az Isten szerette vala”.

${ }^{93}$ A szám utólag beírva az üresen hagyott helyre.

${ }^{94}$ Hallerkői Haller János (1693-1756), 1734 és 1755 között Erdély gubernátora.

95 Utóbbi két szó a margóról beszúrva.

${ }^{96}$ Az évszám és a nap száma eredetileg üresen hagyva, és utólag beírva. A ,februarii reggeli három órakor" pedig ceruzás kiegészítésként a szöveg aljára beírva. - Gödri János jegyzete szerint a családi sírkövön Hajdú István 1748. febr. 28-i temetési dátummal szerepelt, tehát úgy tünik, hogy már az elhalálozás másnapján eltemették. BINDER 2000, i. m. 107. 
2.

\title{
Ismeretlen költö versei a Farkas-ágyú Szebenbe szállításáról (1612)
}

\author{
Ungarisches Gesetzbuch, a 325-326. oldalakon
}

\begin{abstract}
Prosopopeia seu valedictio bombardae Luppi [!] Albae Iuliae e patria migrantis in mense augusto facta, anno domini 1612.
\end{abstract}

Ad notam: Keserves panaszsza jo Magyar országnak

Hallyátok panaszát Fejérvári Volphnak

Utra készülésit N/agysá/gos Farkasnak,

Csudaját sokaknak

Nagy keserüségit ö boltsuzásának.

Igy kezdi keserves szép Orátioját, Hazájátol ékes botsuzo formáját,

Kedves ö Tractaját,

Nagy keserüséges szokkal el válását,

Én keserves Hazám, te Gyula Fejérvár, Edes Atyám, Anyám, szondorlott laktam vár, Jo Bástya Kender Vár,

Ez Világra adott régen tündöklött vár,

Imé én Uramnak nagy parantsolattya, Rajtam -s- az Országnak végezet Tanátsa, El szánt akarattya,

Legyek Magyaroknak segitö Dandárja,

Azért Isten hozzád látod el kell mennem, Az Országgal szükség és [!] egyet értenem, Mindenben engednem,

Fejedelmem mellett nagyotis szenvednem,

Atyai jo voltod ha meg nem háláltam, Szükségnek idejin ha nem szolgálhattam, Oka nem én voltam,

Tisztem szerént mert én mindenkor kész voltam. Tisztem szerint mert én mindenkor kész voltam.
Halljátok panaszát fejérvári Wolfnak, Útra készülésit nagyságos Farkasnak, Csudáját sokaknak,

Nagy keserüségit ő búcsúzásának.

Így kezdi keserves szép oratióját, Hazájától ékes búcsúzó formáját, Kedves ő tractáját,

Nagy keserüséges szókkal elválását.

Én keserves hazám, te Gyulafejérvár, Édes atyám, anyám, condorlott laktam vár, Jó bástya, Kendervár,

Ez világra adott régen tündöklött vár.

Ímé én uramnak nagy parancsolatja

Rajtam, s az egész országnak végezett tanácsa, Elszánt akaratja,

Legyek magyaroknak segítő dandárja.

Azért Isten hozzád, látod, el kell mennem, Az országgal szükséges egyetértenem, Mindenben engednem,

Fejedelmem mellett nagyot is szenvednem.

Atyai jó voltod ha meg nem háláltam, Szükségnek idején ha nem szolgálhattam, Oka nem én voltam, 
Botsánatot adván várjad szolgálatom,

A sok Zürzavarban halesz maradásom, Hozzád én hü voltom,

Ezutánis meglád nyilván megmutatom,

Csak szokatlanságtol félek azt meg vallom, Vizen én nem jártam kitöl iszonyodom,

Nehéz lész ott dolgom,

Jaj melly vénségemre kell uszni tanulnom,

Mind az által imé abban is szolgálnom, Kell fejedelmemnek fejemet hajtanom, Marosban uszkálnom,

De ha kell höségem nem hágy belé halnom.

Vagyon bizodalmom Felséges uramban, Es száraz Dajkámban Szallai Farkasban, Hogy az nagy Marosban,

Segítséggel lésznek ott is ballagtomban,

Sietséggel imé már belé kell mennem, Ne hadgy Farkas Dajkám, énis teprenkedem, Azon igyekezem,

Mint légyen hamaréb által evézésem,

Noszsza, noszsza ne hadgy ki jo akarom vagy, Aki veszedelmem kivanoja nem vagy,

Most segély ha jo vagy,

Vonnyad kérlek vonnyad, ide vesznem ne hagy,

Jaj melly igen nehéz volt lám az mesterség, Vénségemre ímé nálam uj böltseség,

Kihez kell keménység,

Nálamnális erősb mert vizi sebesség.

Szokatlan ez nálam, mert messze nem jártam, Tellyes életemben sohult nem bujdostam, Szomszédban sem voltam,

Esztis vénségemre tanulni indultam.

Elég munkája volt rajtam ki alkutot, De nagyob vann az ki rollam visel gondot, Uszni is oktatot,

Néhéz vénségemre költözni inditot,
Bocsánatot adván várjad szolgálatom, A sok zürzavarban ha lesz maradásom, Hozzád én hű voltom

Ezután is, megládd, nyilván megmutatom.

Csak szokatlanságtól félek, azt megvallom, Vízen én nem jártam, kitől iszonyodom.

Nehéz lész ott dolgom,

Jaj mely vénségemre kell úszni tanulnom.

Mindazáltal ímé, abban is szolgálnom

Kell fejedelmemnek. fejemet hajtanom, Marosban úszkálnom,

De ha kell hüségem, nem hágy beléhalnom.

Vagyon bizodalmom felséges uramban, És szárazdajkámban, Szalai Farkasban, Hogy az nagy Marosban, Segítséggel lésznek ott is ballagtomban.

Sietséggel ímé, már belé kell mennem, Ne hagyj Farkas, dajkám, én is töprenkedem, Azon igyekezem,

Mint legyen hamarébb általevezésem.

Nosza, nosza, ne hagyj, ki jóakaróm vagy,

Aki veszedelmem kívánója nem vagy, Most segélj, ha jó vagy,

Vonjad kérlek, vonjad, idevesznem ne hagyj!

Jaj mely igen nehéz volt lám az mesterség, Vénségemre ímé nálam új bölcsesség, Kihez kell keménység, Nálamnál is erősb, mert vízi sebesség.

Szokatlan ez nálam, mert messze nem jártam, Teljes életemben sohult nem bujdostam, Szomszédban sem voltam, Ezt is vénségemre tanulni indultam.

Elég munkája volt rajtam, ki alkotott, De nagyobb van, az ki rólam visel gondot, Úszni is oktatott, Nehéz vénségemre költözni indított. 
Azért Isten hozzád, hazámnak határa, Ha az hegyen által mehetek Drassora, Onnan Vizaknára,

Tudom bé vezetnek Szeben Piatczára.

Abban is bizonyos vagyok hogy Csudája, Lészek ott sokaknak szemek akadálya, Már volna jutalma, bár tsak egy egy Dénár Dajkámnak az borra,

Illy keserves szókkal valék Hazájátol, N/agysá/gos nagy Farkas ő Kender Várától, Kedves barlangjátol, Lupeskoval edgyütt félvén a marostol.
Azért Isten hozzád hazámnak határa, Ha ez hegyen általmehetek Drassóra, Onnan Vízaknára,

Tudom bévezetnek Szeben piacára.

Abban is bizonyos vagyok, hogy csudája, Lészek ott sokaknak szemek akadálya, Már volna jutalma,

Bár csak egy-egy dénár dajkámnak az borra.

Ily keserves szókkal válék hazájától, Nagyságos nagy Farkas ő Kendervárától, Kedves barlangjától, Lupeskóval ${ }^{97}$ együtt, félvén a Marostól.

Introitus Bombardae Luppi in urbem Cibinianam cum salutatione, mandato et hortatione et combinatione, 25. augusti anno 1612 .

Egésséggel Szeben nyiss kaput utam/na/k, Im én is oltalma lészek köfalodnak, Fogait azok/na/k, ki töröm mind az kik vétnek én Uramnak,

Ne utáld meg ember én eredetemet, Havasi -s- erdei vad természetemet, Cselekedetemet, Hallyad Cronicábol N/agysá/gos nevemet,
Egészséggel, Szeben, nyiss kaput utamnak, Ím én is oltalma lészek kőfalodnak, Fogait azoknak

Kitöröm mind, az kik vétnek én uramnak.

Ne utáld meg ember én eredetemet, Havasi s erdei vad természetemet, Cselekedetemet, Halljad krónikából nagyságos nevemet!

Romulus Romusnak [!], én voltam mind Annya, Romulus, Remusnak én voltam mind anyja, Kegyes emlöimmel nékik szoptatoja Romulus Dajkája, Kegyes emlőimmel nékik szoptatója, Romulus dajkája,

Roma Várossának ki volt Fundáloja, Róma városának ki volt fundálója.

Minthogy azért annak oka és eszköze, Sőt birodalmának voltam mint szekere, mostanis Tüköre, Minthogy azért annak oka és eszköze, Sőt birodalmának voltam mint szekere, Mostan is tüköre, Báthori Nemzetnek vagyok szep Czimere.

${ }^{97}$ Lupesko (Lupescu = ,farkasfi”) alatt minden bizonnyal azt a farkaskölyök-dombormüvet vagy szobrocskát kell értenünk, amely az ágyú irányzékául szolgált. (L. bevezető tanulmányunkat.) 
Mihellyt ez Világra lőn én formálasom, Menydörgö modgyára volt én kiáltásom, Portol rohanásom [!],

Fejedelmem elött három probálásom

Míg fene Farkasok a Veremben Vadnak, Addig a Barmok is békével maradnak, Ha falukra jutnak,

Emberek es Barmok mind meg háborodnak.

Urak Fö Nemesek immár néktek szolok, Az átkozott visszá vonást elhadgyátok, Mert jövendöt mondok, Az Farkastol lészen szaggatva gyomrotok,
Mihelyt ez világra lőn én formálásom, Menydörgő módjára volt én kiáltásom, Portól robbanásom,

Fejedelmem előtt három próbálásom.

Míg fene farkasok a veremben vagynak, Addig a barmok is békével maradnak, Ha falukra jutnak,

Emberek és barmok mind megháborodnak.

Urak, főnemesek, immár néktek szólok, Az átkozott visszavonást elhagyjátok, Mert jövendőt mondok, Az Farkastól lészen szaggatva gyomrotok.

Vége

\section{Családfa: Hajdú István törcsvári porkoláb tágabb családja ${ }^{98}$}

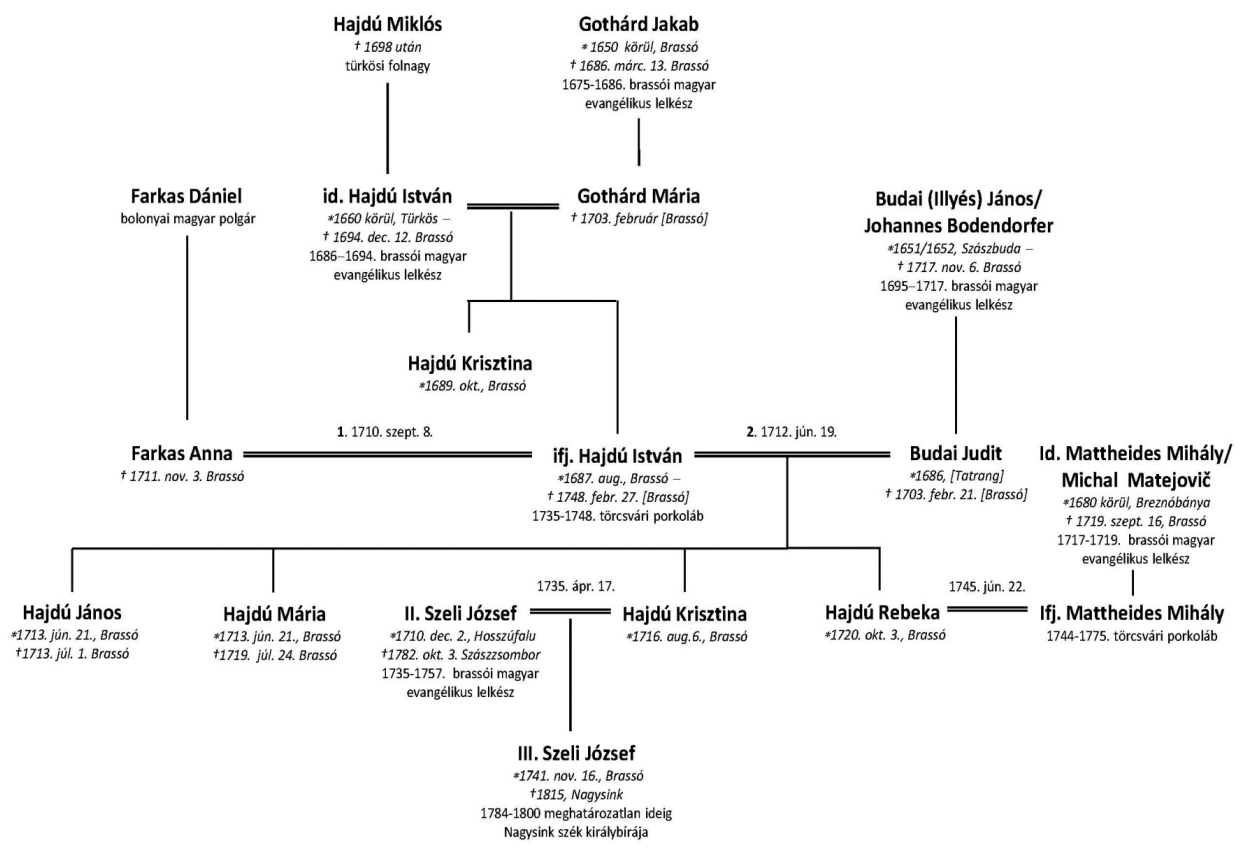

${ }^{98}$ A családfa forrásai: BINDER 1993, i. m., BINDER 2000, i. m. Ungarisches Gesetzbuch. 


\section{BÁNDI, ANDRÁS - SZABÓ, ANDRÁS PÉTER}

\section{Der handschriftliche Band des Törzburger Kastellans Hajdú István - Zwei unbekannte ungarische Gedichte aus der Zeit von Báthori Gábor}

Im Jahre 2001 wurde aus dem Bestand des Schenker-Kapitels eine bisher unbekannte Handschrift des 18. Jahrhunderts in das Zentralarchiv der Evangelischen Kirche A. B. in Rumänien (Hermannstadt) überführt. Der Band wurde hauptsächlich von István Hajdú (1687-1748), Törzburger Kastellan und dessen Schwiegersohn József Szeli (1741-1815), ungarischer Pfarrer in Kronstadt und Langendorf, zusammengestellt und enthält Texte gemischte Gattung, die einerseits zur Erledigung praktischer Aufgaben dienten, andererseits bezeugen sie vom aktiven Interesse der ungarisch-burzenländischen Intellektuellen an der regionalen Geschichte. István Hajdú ist vor allem als Besitzer der ältesten handschriftlichen Gedichtsammlung in ungarischer Sprache bekannt.Im kürzlich entdeckten Band hat Hajdú eine Familienchronik, die zum Teil auf die Ereignisse innerhalb der ungarisch-evangelischen Kirchengemeinde Kronstadts Bezug nimmt, aufgenommen sowie andere Texte juristischen, historischen und medizinischen Inhalts, von denen der interessanteste eine 1723 angefertigte ungarische Fassung vom Landrecht ist (Übersetzer unbekannt). József Szeli fügt dem Band die Leichenrede für seinen Schwiegervater bei und ergänzt ihn mit mehreren historischen Quellen, wie z. B. mit dem Enchiridion (1659) des Martin Harnung, eine Sammlung von historischen und juristischen Notizen zu den Kirchengemeinden des Burzenlandes, oder die lateinische Fassung der Approbatae Constitutiones (1653) des Wurmlocher Pfarrers David Hermann. Der eigentliche Schatz des Bandes sind allerdings zwei bisher unbekannte ungarische Gedichte des 17. Jahrhunderts in der Handschrift des István Hajdú. Handlungsträger und zugleich Erzähler der beiden prosopopöischen Gedichte ist die 1593 durch Fürst Zsigmond Báthori gegossene „Wolf-Kanone“, eine Zierwaffe, die 1612 von Fürsten Gábor Báthori zur Einschüchterung der Sachsen nach Hermannstadt gebracht worden war.

Im zweiten Teil dieses Beitrags werden diese Gedichte aus der Perspektive der Propagandaarbeit der Báthori-Anhängerschaft untersucht. In diesem Zusammenhang sollen einige weniger bekannte Aspekte der Geschichte dieser einzigartigen siebenbürgischen Waffe beleuchtet werden.

Keywords: civilisation history, Hungarian Kingdom, $17-18^{\text {th }}$ centuries, textual tradition, political pamphlet 